\title{
PARÁMETROS NOBILIARIOS Y POLÍTICA DE PRESTIGIO EN EL CONVENTO MADRE DE DIOS DE BAENA (CÓRDOBA)
}

\author{
POR \\ Francisco Manuel CARMONA CARMONA ${ }^{1}$ \\ Universidad de Córdoba
}

\begin{abstract}
RESUMEN
Ofrecemos en esta contribución aquellos factores que se extraen de los elementos materiales conservados y de la documentación archivística custodiada por la comunidad de religiosas dominicas de Madre de Dios de Baena que delatan su vínculo con el linaje de la Casa de Cabra. Valoramos y analizamos sus estatutos fundacionales, los distintos resortes de utilización sociopolítica y propagandística que de este convento se hizo durante los siglos XVI y XVII por los Fernández de Córdoba, así como de los comportamientos que las religiosas desarrollaban intramuros, más propios de la actividad nobiliaria en el siglo que de monjas contemplativas.
\end{abstract}

PALABRAS CLAVE: conventos; nobleza; estatuto fundacional; panteón; heráldica; ceremonial; reliquias; prioras; dote; sagas.

\section{NOBILITY PARAMETERS AND PRESTIGE POLICY IN THE CONVENT MADRE DE DIOS FROM BAENA (CORDOBA)}

\begin{abstract}
In this article, we analyse information extracted from material elements preserved and archival documentation, which reveal the link of the community of Dominican nuns of Madre de Dios from Baena with the lineage of the Casa de Cabra. We analyse their founding statutes, how - from this convent - relatives of the Fernandez de Cordoba family made use of the different resources of sociopolitical and propagandistic intent during the sixteenth and seventeenth centuries. We also describe the behaviour unfolded by nuns within its walls, more akin to members of aristocracy than to those of a contemplative order.
\end{abstract}

KEY WORDS: convents; nobility; founding statute; pantheon; heraldry; ceremonial; relics; prioresses; dowry; family line.

Cómo CITAR ESTE ARTículo / CITATION: Carmona Carmona, F. M. 2019. «Parámetros nobiliarios y política de prestigio en el convento Madre de Dios de Baena (Córdoba)». Hispania Sacra 71, 143: 191-208 https://doi.org/10.3989/hs.2019.014

\author{
Recibido/Received 04-09-2017 \\ Aceptado/Accepted 29-01-2018
}

De la relación entre nobleza y conventos femeninos se han ocupado largamente tanto la literatura apologética como la genealógica, si bien no se han empleado métodos científicos hasta hace relativamente poco tiempo. Si las primeras poseían una clara intencionalidad de vincular la política fundacional y patrocinio de la nobleza señorial con sus estados, la historiografía reciente se esfuerza por poner de manifiesto esta relación en un contexto donde subyace una dimensión política y social de los poderosos. Fue el profesor Domínguez Ortiz de los primeros en dedicar un capítulo a las órdenes femeninas y considerarlo como un instrumento fundamental de las capas dirigentes de la sociedad española y, lo que a nuestro juicio es más importante, destacó el interés que para la Historia social tiene esta parcela del estamento privilegiado. ${ }^{2} \mathrm{~A}$ partir de entonces se fueron sucediendo toda una suerte de aportaciones historiográficas con un desigual ámbito de estudio. Todas ellas esenciales y necesarias pues, de un modo u otro, han dado a conocer numerosos elementos que permiten ponderar la especial relación del noble estamento con las órdenes religiosas y, en concreto, respecto del

1 aa2carcf@uco.es/ORCIDiD:https://orcid.org/0000-0003-1118-3271

2 Domínguez Ortiz 2012: 319-334. 
fenómeno fundacional de conventos femeninos, ayudando a evidenciar más claramente los aspectos políticos, sociales y económicos que ya señalara Domínguez Ortiz. ${ }^{3}$

Destacan en su acercamiento al claustro femenino y su vinculación con la nobleza los aportes de Reder Gadow, ${ }^{4}$ Soria Mesa, ${ }^{5}$ Atienza López, ${ }^{6}$ Barrio Gozalo ${ }^{7}$ y Graña Cid. ${ }^{8}$ De toda esta bibliografía - que aunque escueta es suficientepodemos llegar a extraer determinadas invariantes en la utilización de los conventos femeninos por parte de las élites poderosas, de las que en buena parte participa el convento Madre de Dios de Baena, perceptibles tanto de visu como entresacados de la documentación y bibliografía manejada. Por tanto, entendemos fundamental desvelar aquellos parámetros que funcionaron en este cenobio como inmejorable instrumento de representación y control político-social al servicio de la estirpe que favoreció su fundación y patrocinio, los Fernández de Córdoba de la Casa de Cabra-SessaBaena, y cómo pronto se convirtió en estratégico centro de poder.

Hace ya una década, el profesor Soria Mesa reflexionaba sobre la existencia de un patrón de comportamiento común a la nobleza en el terreno del clero femenino de la España moderna, advirtiendo seguidamente que desconocía «un solo trabajo que intente desvelar las identidades sociales de todas esas sores que a veces encubren sus apellidos con un Santa María, Jesús o cualquier santo o miembro de la

\footnotetext{
3 «El interés historiográfico por los conventos femeninos y por las mujeres que en ellos pasaron sus días tiene ya bastante recorrido, es uno de los temas que sigue resistiendo bien el paso del tiempo, aunque es cierto que el balance que se ofrece es muy disperso y esto ha condicionado mucho la visión final que predomina. Una muy concisa y rápida 'fotografía' del panorama presente nos sitúa ante un gran número de estudios publicados en revistas, y sobre todo en actas de congresos específicos. Contamos así con un gran número de contribuciones que en su mayoría son de carácter puntual en su temática y en su objeto: muy frecuentemente, un convento específico. En menor medida disponemos de aproximaciones de perspectiva más amplia, y el escenario resultante es el de un mundo de importantes diferencias que dificultan la síntesis y las perspectivas generales, porque, además, las dificultades no remiten únicamente a cuestiones de cantidad. También es perceptible la variedad de enfoques, formas y claves interpretativas con las que los historiadores nos hemos enfrentado a la investigación en este campo» (Atienza López 2012: 90).
}

4 Reder Gadow 2000; ofrece una metodología de estudio y análisis del conventualismo femenino como contribución a la Historia social.

5 Soria Mesa 2007: 162-173; si bien toda la obra está jalonada por referencias al binomio nobleza-claustro, anima a la investigación partiendo de cinco características básicas o hipótesis de trabajo para realizar estudios familiares sobre la nobleza hispana y su relación con el fenómeno conventual femenino.

6 Atienza López 2008; obra en la que se ha sustanciado gran parte de la aportación a esta temática. Atienza López 2010; donde evidencia la dimensión político-social en el vínculo fundaciones conventualesseñores-señorío y «la lógica del mantenimiento, fortalecimiento y reproducción del régimen señorial y de la propia aristocracia como clase dominante». Atienza López 2012; por el cual nos abre un abanico de retos en la investigación de aspectos aún poco desarrollados sobre el mundo de las monjas y sus conventos.

Barrio Gozalo 2010; ahonda en el último capítulo de su obra para señalar a través de la intrahistoria conventual determinados rasgos esenciales de la nobleza.

8 Graña Cid 2012; nos señala las características del reforzamiento de las competencias e intereses nobiliarios que sobre las monjas de obispado de Córdoba se ejercieron durante la primera mitad del siglo $\mathrm{XVI}$. corte celestial, [...] impidiendo conocer nada en concreto, ni afirmar hecho alguno, más allá de la omnipresencia del fenómeno en el seno del estamento privilegiado ". ${ }^{9}$ Por suerte, del convento Madre de Dios de Baena, en lo que se refiere al siglo XVI y hasta buena parte del XVIII, podemos afirmar que en la mayoría de los casos detrás de los nombres de profesión existen apellidos, padres y familias, sabemos de dónde proceden, sus edades de ingreso en el convento y por qué salen para no volver más, quiénes y cuánto pagan por sus dotes y por qué no las pagan al profesar, la categoría del religioso que impone el velo, e incluso en algunos casos sus minusvalías físicas o cuándo y de qué mueren. Estos y algunos ítems más son los que nos proponemos entresacar, para establecer los parámetros definidores de la idiosincrasia de esta comunidad y cómo son imagen especular de los comportamientos de la nobleza que la auspició, además de intentar descubrir cómo Madre de Dios de Baena se convierte en instrumento y plataforma a su servicio.

La relación directa entre los Fernández de Córdoba y la comunidad de religiosas de Madre de Dios de Baena se evidencia gracias a la bibliografía genealógica y, sobre todo, con el limitado pero enjundioso archivo que custodia, constituyéndose en un verdadero altavoz de la utilización de este convento en la dimensión socio-política del linaje. Tanto, que permite un análisis profundo gracias a las informaciones que se extraen fundamentalmente de los estatutos y letras apostólicas $^{10}$ y los sustanciosos Libro de profesiones ${ }^{11}$ y Libro de hacienda. ${ }^{12}$ Pero además, en el archivo conventual sobresalen de la desigual documentación conservada -en tan solo cinco cajas-, informaciones relativas al aparato de significación de la familia condal-ducal.

Sobre la actividad fundacional de la rama de Cabra de los Fernández de Córdoba podríamos decir que fue cuanto menos intensa, contribuyendo con ímpetu a la expansión conventual de sus estados -Cabra, Baena, Albendín, Iznájar, Rute y Doña Mencía- y también fuera de ellos, pues no en balde formaban parte del linaje más poderoso de la ciudad y reino de Córdoba. Obligado es advertir la estrecha relación y mutuo aprovechamiento que desde largo ha tenido esta Casa con la Orden de Predicadores, ${ }^{13}$ puesta en evidencia tanto por la literatura genealógica como por los historiógrafos dominicos. ${ }^{14}$ De un lado, los dominicos se veían favorecidos

9 Soria Mesa 2007: 169-170.

10 Archivo Conventual Madre de Dios de Baena (ACMDB). Caja (C.) 2, Estatutos y letras apostólicas. (en adelante Estatutos y letras apostólicas, sin su localización).

11 ACMDB. C.4, Libro de profesiones (en adelante Libro de profesiones, sin su localización).

12 ACMDB, C.1, Libro de hacienda (en adelante Libro de hacienda, sin su localización).

13 Miura Andrades 1988b: 288, nos señala el motivo de la fecunda relación de la alta nobleza española con la orden dominicana.

14 Abad de Rute 1954; Fernández de Béthencourt 2003: tomo (t.) 7 y López Caparroso 1622 passim dejan meridiana idea de la predilección de la Casa de Cabra por la Orden de Predicadores, tanto para sus fundaciones monacales como para que sus miembros vistieran el hábito de Santo Domingo. Por su parte Huerga Teruelo 1992: 240 se refiere al fuerte vínculo del linaje de los condes de Cabra con los dominicos andaluces, y «de ese árbol, por vía legítima o por injerto bastardo, procedieron personajes muy ilustres como fray Francisco de la Cerda y fray Martín de Mendoza: Ios dos provinciales y luego obispos [ambos asisten al Concilio de Trento]. Don Diego Fernández de la Cerda fundó el convento-parroquia de Doña Mencía. Su hijo [tercer conde de 
con fundaciones conventuales y patronazgos por parte de los Fernández de Córdoba, ayudando así a establecer su entramado conventual en los territorios reconquistados. De otro, los segundones se veían favorecidos al vestir el hábito de Santo Domingo y luego verse destacar en distintos empleos de la orden o escalados a las más altas dignidades eclesiásticas. Como no podía ser de otro modo, el convento Madre de Dios de Baena se fundó atento a la jurisdicción dominicana ${ }^{15}$ en 1510 por los terceros condes de Cabra, don Diego Fernández de Córdoba y doña Francisca de Zúñiga, «por devoçion que a la dicha orden tienen quieren y an por bien que sea de la orden del señor santo Domingo y que este subjeto al dicho Provinçial y Vicario e Congregación ». ${ }^{16}$

El obispo de Monopoli nos señala como principal motivación para la institución del cenobio baenense la reciente toma de estado de doña Juana de Santo Domingo y Cerda, hija de los terceros condes de Cabra, quien habría profesado en el año 1500 en el convento Santa María de los Ángeles de la ciudad de Jaén. ${ }^{17}$ Por su parte, Miura Andrades motiva la inceptio $^{18}$ del convento Madre de Dios de Baena a lo prolífico que resultó el matrimonio condal, con un total de 14 hijos legítimos más los 5 ilegítimos mencionados por el conde en su testamento. ${ }^{19}$ De las siete hijas legítimas solo tres obtuvieron un matrimonio homogámico, pasando las cuatro restantes a ocupar un sitial en el coro de Madre de Dios, a las que habría que sumar dos hermanastras. Todo ello nos indica que debieron existir problemas de casamiento para todas ellas y, por tanto, Madre de Dios se constituyó en el más adecuado refugio para las célibes forzosas de este linaje. ${ }^{20}$

\section{LOS ESTATUTOS FUNDACIONALES}

En la documentación manejada descubrimos que Madre de Dios participa en gran medida de lo que la bibliografía científica especializada viene en denominar como capital social y político, esto es, un convento «destinado a garantizar el mantenimiento y la reproducción de la dignidad y el honor familiar indispensable para la nobleza y las familias más pudientes», por cuanto -histórica y antropológicamente- se defiende que

Cabra] fue muy prolífico y 'colocó' nada menos que a siete vástagos en la Orden y funda un monasterio-esponja para sus hijas y el de Nuestra Señora de Guadalupe en Baena». Mientras que Miura 1988b: 288-291 precisa sobre los motivos y la fecha de esta relación, cuando a comienzos del siglo XV el señor de Baena acudió a los dominicos de San Pablo de Córdoba para dotar de servicios religiosos el recién repoblado lugar de Doña Mencía.

15 «Este convento de Madre de Dios desde su fundación ha estado inmediato [en glosa:] a los padres provinciales y no puede ser visitado si no es de las mismas personas de los superiores o del $\mathrm{R}^{\mathrm{mo}}$ General o del padre provincial de esta Provincia y no de otro, ni visitador, ni prelado fuera de los dos referidos", Libro de hacienda, folio (f.) 330r Todo ello confirmado por el Maestro General de la Orden, fray Sixto Fabio de Luca, en diciembre de 1588. Estatutos y letras apostólicas, folios (ff.) 33-34.

16 Estatutos y letras apostólicas, ff. 1-2.

17 López Caparroso 1622: 205v-206r. Huerga Teruelo 1992: 367-370.

18 Sobre los distintos pasos jurídicos y etapas fundacionales en conventualismo vide Miura Andrades 1988a: 75-82.

19 Fernández de Béthencourt 2003: t.7, 84. Y según el libro registral conventual habría que añadir una hija bastarda más, sor Dominga de Madre de Dios, quien ingresó siendo aún muy niña y profesó en 1535. Libro de profesiones, f. 10v.

20 Miura Andrades 1988b: 287-288. «el honor familiar se representaba en buena medida a través de la mujer", y nada mejor que un convento para conseguirlo. ${ }^{21}$ Pese a que los estatutos de fundación del convento, las bulas apostólicas confirmatorias, así como los privilegios y mandatos de los generales de la orden nos hablan de limitaciones, prohibiciones y de la obligada obediencia debida, pero también se nos informa de ciertas prerrogativas, exenciones y privilegios que difícilmente pudieran haberse conseguido si no fuera por el fuerte carácter nobiliario de este cenobio. ${ }^{22}$

Ciertamente, a la luz del estatuto de fundación de este convento baenense, podemos llegar a conocer los verdaderos motivos de don Diego y doña Francisca para que el 20 de febrero de 1510 concertasen unos estatutos fundacionales, donde se explicita escuetamente el deseo y la voluntad de establecer monasterio en Baena, para que lo habiten treinta y cinco monjas naturales de las villas y estados del conde fundador. Se expresa además en sus cláusulas la necesidad que entren en religión cuatro de sus hijas y establecen el derecho de presentación de parientas de hasta el cuarto grado. Para facilitar el establecimiento dominico ceden provisionalmente unas casas que poseen entre la iglesia mayor y el palacio-fortaleza, ${ }^{23}$ que serían ocupadas por un máximo de doce religiosas hasta tanto concluyera la obra del nuevo monasterio en otro lugar de la villa. Además, asignan una considerable dotación inicial, que a su entender es suficiente para el sustento de la docena de madres fundadoras, estableciéndose la necesidad que las nuevas entradas sean «con crecido dote». ${ }^{24}$

\section{No se reçiba si no fuere parienta}

Se evidencia en los estatutos fundacionales de Madre de Dios cómo los condes estaban atentos a dar respuesta al problema de no poder concertar matrimonio en correcta homogamia a todas sus hijas, habida cuenta de su numerosa prole y el ahorro que les supuso meter monja a cuatro hijas, ${ }^{25}$ frente a la enorme inversión necesaria para conseguir un matrimonio honroso. Pero como fue costumbre en

21 Atienza López 2008: 308, apud Morant y Bolufer 1998: 50.

22 Sin ánimo de ahondar en esta peculiaridad, llama la atención la cita de Abad de Rute 1954: 377: «el convento Madre de Dios de Baena, monjas de la Orden de Santo Domingo, uno de los más insignes que su religión tiene por calidad de sangre, pues hay siempre en él señoras de esta Casa y de otras de las más ilustres de España, y mucho más por la del Espíritu, dándosela grandes Santas que nunca han faltado en aquellas nobilísimas en todo».

${ }_{23}$ "La casa era lo que es ahora noviciado, cae detrás de las capillas y sacristía del conde [y] aunque pequeña por ser de prestado hasta buscar otro sitio y más largura se puso la clausura, comenzó el oficio divino, misas y rezado en comunidad y oficinas conforme a la pequeñez de la casa y sitios». Libro de hacienda, f. 279r y glosa al margen.

24 Estatutos y letras apostólicas, ff. 1-5.

25 Conceptos como el de 'excedentarias' o 'aparcadas' están largamente advertidos por la bibliografía especializada. No obstante, desde unos años acá se ofrece un giro interpretativo considerando el ingreso de las mujeres en el convento como una "estrategia de equipo en el seno de la familia», lo que según Atienza da respuesta a la pregunta: "¿Hasta qué punto obligación, en un sentido de imposición y de exigencia, de experiencia sentida como coacción o hasta qué punto comportamiento responsable, asunción de un compromiso en el seno familiar, cumplimiento solidario de un deber, participación activa en ese 'juego', y no solo asunción pasiva? [Lo que cabe interpretar] que una parte del papel de las monjas en los conventos seguía teniendo mucho que ver con los intereses de sus familias» (Atienza López 2012: 98-101). 
las cartas fundacionales, se intentó dar remedio no solo a las necesidades de la familia directa, sino también a la parentela más cercana. Un perfecto ardid para ampliar y reforzar las relaciones clientelares.

El derecho de presentación también se hace patente cuando los fundadores establecen un número máximo de treinta y cinco profesas y «no se reçiban monjas de otra parte si no fuere parienta dentro del quarto grado del conde y condesa o de qualquiera de ellos de los que ahora son o de los que suçedieren en su casa y pidiéndolo ellos. Pero si por caso alguna persona quisiere entrar en el dicho monasterio con creçido dote e de que en sí espere utilidad a la dicha casa». ${ }^{26}$ Pero este estatuto llegó a ofrecer dificultades interpretativas a tenor de lo contenido en la bula confirmatoria de Paulo III de 1537, donde se especifica «no pudiese aver mas de treintayçinco monjas contadas las noviçias y prophesas sino es que alguna pidiese ser reçebida, la qual truxese cierta conveniente dote»; ${ }^{27}$ un asunto este en el que insiste en 1545 fray Francisco de la Cerda, hijo de los fundadores y por entonces provincial de la orden en Andalucía. La situación debió complicarse y provocar arbitrariedades en la entrada de religiosas y el orden de prelación, por lo que obliga en 1630 al provincial fray Juan de los Ángeles a perfeccionar jurídicamente estas disposiciones, ${ }^{28}$ Ilegando a declarar que:

... en caso que haya vacante tienen primer lugar las parientas de los señores condes en la forma dicha. Segundo lugar las que trajeren dote crecida. Tercer lugar las naturales de la tierra [...] pues el señor don fray Francisco de la Cerda, hijo legítimo del señor conde, siendo provincial de esta provincia y teniendo noticia de estos estatutos en la ordenaciones que hizo para este convento no hizo mención de esta gracia para sus parientas, siendo tan natural a todos los hombres no limitar sino aumentar favores a su propia sangre y a los hijos llevar adelante la voluntad de sus padres. ${ }^{29}$

\section{Si quisiere entrar con creçido dote}

De todo lo anterior se infiere que la nobleza y el dinero son las llaves principales que abren las puertas del convento. Por esto abundó fray Juan de los Ángeles en establecer un criterio que determinase la cuantía a partir de la cual «pueda llamarse aventajado dote, y que con el sea la casa muy aprovechada [...] y declaro que la dote de las supernumerales para cumplir con la obligación y descomunión de este estatuto han de ser mil y quinientos ducados y no menos». ${ }^{30}$

Del análisis de las informaciones que se desprenden de los libros, se observa que esta situación de superpoblación conventual se viene dando desde 1596, pero únicamente a sor Juana de la Columna, hija de los vizcondes de las Torres y parientes de los condes de Cabra, es a quien se exige para profesar en 1647 los 1.500 ducados estipulados por fray Juan de los Ángeles en 1630, por «entrar sobre el número y por esta razón se concertó dote distinta, pagadera al tiempo de su profesión». ${ }^{31}$

\footnotetext{
26 Estatutos y letras apostólicas, cláusulas 3a y 4ạ , f. 2.

27 Ibídem, f. 6.

8 Ibídem, ff. 19-25.

29 Ibídem, f. 22.

Ibídem, f. 23

1 Libro de profesiones, f. 57r-v.
}

\section{Naturales de Baena e Cabra e la otra tierra del conde}

Son escuetos los estatutos fundacionales sobre los derechos de presentación, pronunciándose solo sobre la reserva de plazas para las cuatro hijas de los condes, y que el resto sean de las villas y estados de la Casa. Esta libertad en la designación de plazas se debió traducir en pugna por un sitial en el coro, un verdadero instrumento de significación de los poderosos villanos, quienes verían con fruición el tener reunido un miembro de su familia junto a otras sores pertenecientes a la alta nobleza española. Esta situación que vendría siendo lo habitual durante todo el siglo XVI y XVII se vio extremadamente limitada durante las primeras décadas de existencia del cenobio, observándose una monopolización en sus exiguas doce plazas.

Tal y como hemos visto, se establece estatutariamente que el convento se funda para que en él fuera primera priora perpetua una hija de los fundadores, ${ }^{32}$ acompañada de las cinco sores del convento jienense, ${ }^{33}$ y desde el día del establecimiento fundacional ingresara otra hija de los condes, ${ }^{34}$ y al poco, otra más. ${ }^{35}$ Esto supone una población inicial de más de la mitad del número permitido por don Diego y doña Francisca, y hasta completar el número de doce se cuidó mucho la ascendencia y caudal aportado por las novicias admitidas. Lo fueron primeramente dos hijas del bachiller Bartolomé Fernández de Mesa, alcaide mayor de Baena, ${ }^{36}$ y Beatriz, hija de Ramiro de Valenzuela, hombre de confianza del fundador. ${ }^{37}$ Completó el cupo doña María de Mendoza, hasta ahora una desconocida hija ilegítima del obispo de Palencia don Francisco de Mendoza, hermano del conde de Cabra. ${ }^{38}$ Las prontas defunciones de dos sores permitieron la entrada de las hermanas Nogueras, dos hijas de Martín Noguera, prohombre de la villa, y a los pocos días, dos hijas de don Juan de Herrera, alcaide de Priego,

32 Doña Juana de Santo Domingo y Cerda vino profesa desde Jaén, pasando automáticamente a ostentar el cargo de priora en Madre de Dios con tan solo 16 años. Por su corta edad se nombró como supriora a la madre Isabel de la Paz. Murió en 1546 como priora perpetua. Libro de profesiones, ff. 2v, 3v; López Caparroso 1622: 205v; Lorea Amescua 1681: 187.

33 Sor Isabel de la Paz, priora en Jaén y supriora en Baena (†1515); sor Ana de Santo Domingo (†1530); sor Catalina de Valdecañas (†1544); sor Teresa Fernández (†1566) y sor Isabel de Padilla, quien «en 1534 salió por priora y fundadora del monasterio que hizo Fernando de Zafra en Granada y de allí la llevaron a Torrejimeno por priora y fundadora» (Libro de profesiones, ff. 2v-3r).

34 Sor Brianda de Santo Domingo, a quien «no se le dio hábito por ser niña de ocho años, fue priora veinte años después de mi señora doña Juana, murió en 1567» (Libro de profesiones, f. 3v).

35 Doña Ana del Espíritu Santo de la Cerda tomó hábito en 1513 y profesó en 1523, "fue priora por seis años y murió en 1573» (Libro de profesiones, ff. 3v-4r).

36 Alcaide Mayor de la villa de Baena desde 1508 a 1520. Ruiz Arjona 1986: 44. La dote que aporto por ambas hijas fue de 50.000 maravedís (mrs). Libro de profesiones, f. 4r.

37 Su dote ascendió a $20.000 \mathrm{mrs}$, que se quedó el convento tras su muerte a poco de tener entrada. Libro de profesiones, f. 4v. A Ramiro de Valenzuela nos lo muestra La Historia de la Casa de Córdoba como criado aventajado del conde de Cabra al que considera "su pariente» y documentado como su albacea testamentario (Abad de Rute 1954: 148, 395-396; Fernández de Béthencourt 2003, t.7: 72).

38 «dieronle de dote cien mil maravedís, echaronse en censo a diez mil el millar, recibieronse en tres partidas como se verá por el libro viejo [...] Falleció la dicha [sor María de Santo Domingo] víspera de Santa Lucía [de 1513]» (Libro de profesiones, ff. 4v-5r). 
siendo una de ellas «muy niña», a la que siguió sor María de Jesús, sobrina del fundador, quien también «entró muy niña», como también lo era Elena, hija del jurado baenense Juan de Morales y una de las dos hijas que ingresó don Bernardino Fernández de Córdoba y Ponce de León, primo hermano del tercer conde de Cabra.

Todo lo anterior nos indica, de un lado, que aún en vida del conde fundador los acuerdos fundacionales fueron cuanto menos de aplicación poco rigurosa, si bien es cierto que estos nuevos ingresos fueron por igual de niñas de corta edad o educandas, como de novicias que tomaban hábito de obligación. Por otro lado, no pasa desapercibida la dignidad de la ascendencia de estas monjas, un verdadero ejemplo de política de prestigio del conde, capaz de desdecirse en sus condiciones estatutarias en pos de un provecho clientelar. $Y$ por último, es conveniente advertir la ya señalada estrechez de aquellas casas provisionales cedidas por los condes y la necesaria y conveniente mejora en la economía conventual que precisaba vinieran todas ellas con dotes aventajados. ${ }^{39}$

\section{Que se ha de fazer monasterio e iglesia}

La provisionalidad y angostura de las casas que ocuparon la comunidad fundadora pasó a ser definitiva y considerablemente ampliada, pues para 1534 «era la comunidad de este convento de más de treinta monjas, se había alargado la casa con intención de hacer pie en ella y no mudanza a otra parte ${ }^{40}$ constatándose de la documentación archivística cómo desde pronto se fueron comprando y añadiendo las casas vecinas al convento original. Todo ello nos indica que la ubicación del convento debió entenderse como estratégica, entre el castillo y la iglesia, de ahí el que no se hiciera traslado a otra parte pese a que en la escritura de fundación se especificaba lo contrario. ${ }^{41}$

A partir de 1525, año del fallecimiento del fundador, y por encontrarse el cabeza de la Casa en tierras italianas, propicia que las disposiciones fundacionales se disipen. Lo cierto es que Madre de Dios comienza desde entonces a operar en la Almedina baenense de forma primordial e incuestionable como hito simbólico y representativo de primer orden en las pretensiones nobiliarias. Su archivo nos permite entresacar dos factores fundamentales sobre las que descansa la no mudanza a otro lugar de la villa. El primero es la posibilidad de entender el convento como gineceo o lugar de habitación para el sector femenino de linaje -hasta tanto se concreta el estado que ha de tomar-, habida cuenta de la conexión que existe entre el castillo señorial y el cenobio mediante un pasadizo elevado -hoy Arquillo de la Villa, convertido en mirador-, señalando el

39 «... aunque habían entrado las madres Nogueras trajeron la dote en la Haza Puertas de Valenzuela y un olivar, el dinero poco. También había entrado otras cuatro o cinco novicias y la señora doña María Carrillo niña, pero con la parte de situado se iba pasando y con las dotes no podía subir en tan breve tiempo y pocas monjas, pues las dotes no eran más de 30.000 mrs y la subida de las señoras, particularmente las hijas del conde y más las niñas estaban siempre piando y pidiendo a su padre y las monjas a Dios que es quien abre los tesoros y alholíes de los ricos y poderosos». Lo que en 1516 suponía una renta anual de 48.500 mrs según se desprende la visita del padre provincial fr. Cristóbal de Guzmán. Libro de hacienda, f. 279v.

40 Ibídem, f. 281v.

41 Alegre Carvajal 2004: 115-121. archivo conventual un arbitrario trasiego de situaciones y de personal palaciego al convento y viceversa. El segundo, es la cercanía con el aún inédito beaterio emparedado a Santa María la Mayor, que más pronto que tarde se incorporaría a nuestro convento, y del que se da noticia de su existencia en la documentación conventual. ${ }^{42}$

\section{UNA FUNDACIÓN PARA LA FAMILIA}

Un punto de inflexión en la situación que hemos detaIlado tuvo lugar en 1525, tras la muerte del III conde de Cabra, y gracias a la decidida proyección dada al convento por su hija doña María Carrillo de Córdoba, quien entró en el convento como educanda en 1516 y no profesó hasta que no recibió la herencia de su padre. De los bienes que le cupieron en parte junto a sus seis hermanos varones pagó su dote, considerándose entonces "la mayor herencia que el convento ha tenido de monja ha sido de esta señora». ${ }^{43}$ En 1526, el día de su profesión, le dedicó sermón e impuso el velo su tío don Francisco de Mendoza, obispo de Palencia, ${ }^{44}$ a nuestro entender figura clave en la estrategia seguida por su sobrina. La formidable dote aportada por doña María, ${ }^{45}$ unida a la intención de convertir la iglesia conventual como patronato perpetuo y lugar donde descansaran los restos del prelado, serían determinantes en el impulso dado a Madre de Dios. ${ }^{46}$ Por tanto en un aún incierto momento comprendido en el decenio 1526-1536 podemos llegar a considerar la receptio loci, por cuanto se emplaza definitivamente el convento en las casas fundacionales, ocasión en la que se comienza una decidida renovación y ampliación arquitectónica en nuestro cenobio y participando de un sistema coherente de comunicación visual capaz de influir en la población de forma persistente. (Fig. 1)

42 Libro de profesiones, f. 11r; Libro de hacienda, ff. 209r y 269r; ACMDB. C.3, Testamento del obispo de Palencia (17.01.1536), f. 24r. Podemos llegar a establecer los motivos y origen de este beaterio gracias a las tangenciales informaciones de la bibliografía genealógica cuando se refiere a Isabel de Haro, quien pese a considerarla doncella de noble linaje, la privan del tratamiento de doña. Era madre de los hijos ilegítimos del obispo de Palencia, a quien «estando encinta, don Francisco y el conde de Cabra, su hermano mayor, le pusieron casa muy principal donde vivió muy honesta y recogidamente y tenida en mucha reputación, hasta hacer en su propia morada la vida de clausura, y allí falleció repentinamente sin testar, siendo enterrada en el convento de la Madre de Dios». De esta relación nació don Diego, quien ejerció diversos oficios tanto eclesiásticos como reales, fue abad de Castrojeriz (Burgos) y obispo electo de Ávila (Fernández de Béthencourt 2003, t.7: 66-67). En su testamento instituye una capellanía «de las heredades [...] así muebles como inmuebles que yo tengo en Baena y quedaron de mi señora Isabel de Haro, que sea en Gloria, mi madre [...] la cual se ha de servir y las misas que se han de dar en el monasterio de Madre de Dios de monjas de Baena donde están enterrados mis padres" (ACMDB. C.2, Testamento del obispo de Ávila, f. 10r).

${ }^{43}$ Libro de profesiones, ff. 6v-7v. Una copia de su testamento en ACMDB, C.3.

44 Libro de profesiones, ff. $6 \mathrm{v}$.

45 La riqueza de doña María y el no haberse concertado su matrimonio no hace sino reforzar la tesis ya señalada por Atienza López 2012: 98-101. Vid nota 25.

46 «... el señor Obispo de Palencia, hizo heredero a este convento de toda la riqueza que tenía y piezas de valor de su sacristía, quiso enterrarse en la capilla [mayor] de la iglesia de este convento» (Libro de hacienda, f. 266r). 
FIGURA 1

Vista de Baena (circa 1950) con el convento Madre de Dios entre los restos del castillo e iglesia mayor de Santa María

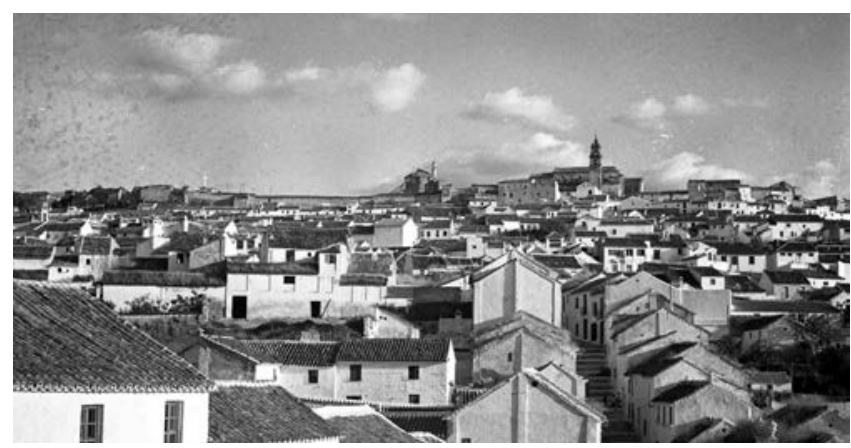

Fotografía: Archivo Diputación de Córdoba. Catálogo Histórico Artístico Provincial, Baena: A320-214.

\section{Panteón familiar}

Pese a los desvelos y sacrificios económicos tenidos por el obispo de Palencia, problemas testamentarios obligaron a depositar sus restos a los pies de la iglesia conventual, bajo la cratícula que abre al coro. Todo indica que debió existir un acuerdo entre el III conde de Cabra y su hermano, el obispo de Palencia, para que este se constituyera en patrón de la iglesia conventual, habida cuenta de que el fundador de Madre de Dios escogió la capilla mayor de la lindera iglesia de Santa María para su enterramiento, ${ }^{47}$ y que el prelado en su testamento establece:

... que mi querpo sea sepultado en la iglesia del monasterio de Madre de Dios de la orden de Santo Domingo de monjas de la villa de Baena, en la capilla mayor de la dicha iglesia y monasterio. / Item digo que yo soy obligado porque así lo prometí al conde [de Cabra] mi señor, que Gloria aya, de hacer la capilla mayor del dicho monasterio, quiero y mando que al tiempo de mi fallecimiento [...] se haga una capilla de cantería onesta que sea donde a de estar el altar mayor de la iglesia y el Sacramento y se haga un retablo y reja sin mucha costa, y que la dicha capilla se acabe conforme a la traza questa hecha [...] y que en ella no se entierre otra persona salvo deudos de la casa con licencia y mandamiento del señor de la casa de Baena. ${ }^{48}$

Y así fue, su obligación le llevó «a edificar como se parece en sus fundamentos hasta los escudos y arco hasta las repisas, y todo lo cual mandó y comenzó en vida y sus albaceas prosiguieron", hasta que un pleito iniciado por su sobrino don íñigo de Córdoba impidió continuar las obras y obligando al convento a concluirlas años más tarde de su propia tesorería. ${ }^{49}$ Pese a ello, en los pilares del arco

47 Carmona Carmona 2017a: 20; 2017c: notas 36 y 37

48 ACMDB. C.1, Testamento del obispo de Palencia, ff. 13r-14r.

49 «Los albaceas los volvieron para pagar ciertas deudas que salieron y particularmente una tutela del señor íñigo de Córdoba [y Aguayo, corregidor de Guadix], de la cual no se habló ni trató en vida del señor obispo, sino a cabo de muchos años después de muerto. Fue la demanda y cargos de manera que apenas hubo en la hacienda para llenarlos, así se llevaron todos los bienes, si algunos hubo el convento fue por su justo valor y precio sacados de la almoneda y pagados con sus dineros, y el convento acabo de labrar la capilla con su hacienda y la puso en la perfección y estado que tiene en lo cual gastó más de tres mil y quinientos ducados como parece por los papeles y gastos de obras ordinarios, sin los extraordinarios, y así el señor obispo se
FIGURA 2

Capilla mayor de la iglesia conventual de Madre de Dios y detalle de uno de los blasones del obispo de Palencia, don Francisco de Córdoba y Mendoza, en los pilares del arco toral.
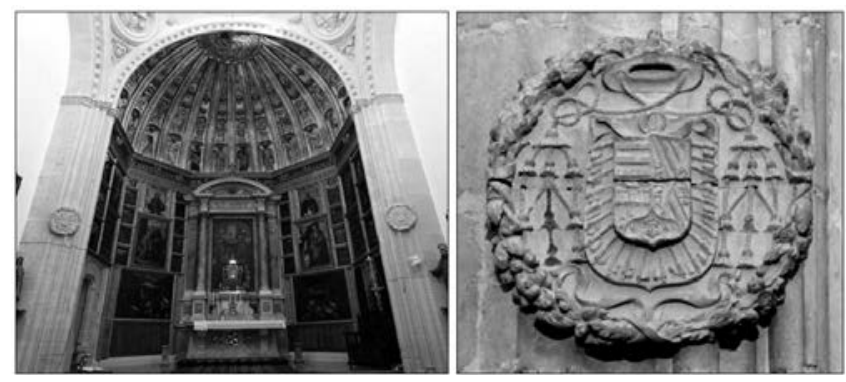

Fotografías del autor.

toral aún campean los blasones del prelado palentino don Francisco de Córdoba y Mendoza (Fig. 2).

Otro obispo de la Casa de Cabra, don Francisco de la Cerda (†1551), electo de Canarias, también está enterrado en Madre de Dios. Ocupa el mismo lugar que su tío el obispo de Palencia $-y$ presumiblemente también que Isabel de Haro, vista su relación de amancebamiento- bajo la reja que abre al coro. Para tan principales entierros se labró una lápida que está adosada al muro del comulgatorio con los nombres de los ilustres obispos de la familia, en la que se incluye al obispo de Córdoba, don Martín de Córdoba y Mendoza (†1581). Este prelado cordobés era hijo ilegítimo del conde fundador y hermano carnal de la que en el año de su fallecimiento fuera priora, sor Leonor de Cristo. ${ }^{50}$ Tanto genealogistas como historiadores de la villa sostienen que don Martín se encuentra enterrado en Madre de Dios al dar por concluyente la epigrafía; sin embargo los libros conventuales nos informan que no fue así, lo que a todas luces nos está indicando que se trata de un claro intento de dignificación y significación de los hijos bastardos del conde don Diego ${ }^{51}$ (Fig. 3).

Sin duda en este aspecto el mejor documento, por elocuente, es el Libro de los entierros, donde hasta circa 1645 se enumeran y relatan las implicaciones que para con el convento de Madre de Dios de Baena tuvieron los bienhechores y miembros de la Casa de Cabra enterrados

quedó depositado en el entierro del coro y comulgatorio para casa propia hasta el día último» (Libro de hacienda, f. 266r). En 1558 la iglesia aún se estaba edificando, según se desprende del Libro de profesiones, ff. 23v-24r, con el empleo de los 1.000 ducados de las dotes y 100 de ajuar de dos hijas de don Íñigo.

50 Sor Leonor de Cristo, hermana entera del obispo Don Martín y don Bernardino de Córdoba. Fernández de Béthencourt 2003, t.7: 86 y Abad de Rute 1954: 398. A los seis años entró en el beaterio que estaba incorporado con la iglesia de Santa María la Mayor de Baena, "que está a una reja que sale de la iglesia» (Libro de hacienda, f. 209r). Gobernó la comunidad 21 años, de estos 12 de priora. Falleció en 1601. En el año del fallecimiento de su hermano, el obispo don Martín, se la documenta en el oficio de priora. Libro de profesiones, ff. $9 v$ y $25 v-32 r$.

51 Libro de hacienda, ff. 267r-v. También lo advierte ACMDB. C.4, Libro de los entierros, f. 1v (en adelante Libro de los entierros, sin su localización): «en confianza de que Su Santidad nos concedería breve para traer al dicho entierro el cuerpo del señor don fray Martín de Mendoza [...] la Santa Iglesia de Córdoba contradijo y suplicó a Su Santidad que no nos concediese el breve dicho, por lo cual no se cumplió nuestra pretensión, solo quedó escrita en piedra». 
FIGURA 3

Reja con cratícula a los pies de la iglesia conventual. Abajo, detalle de la lápida de los obispos de la Casa de Cabra
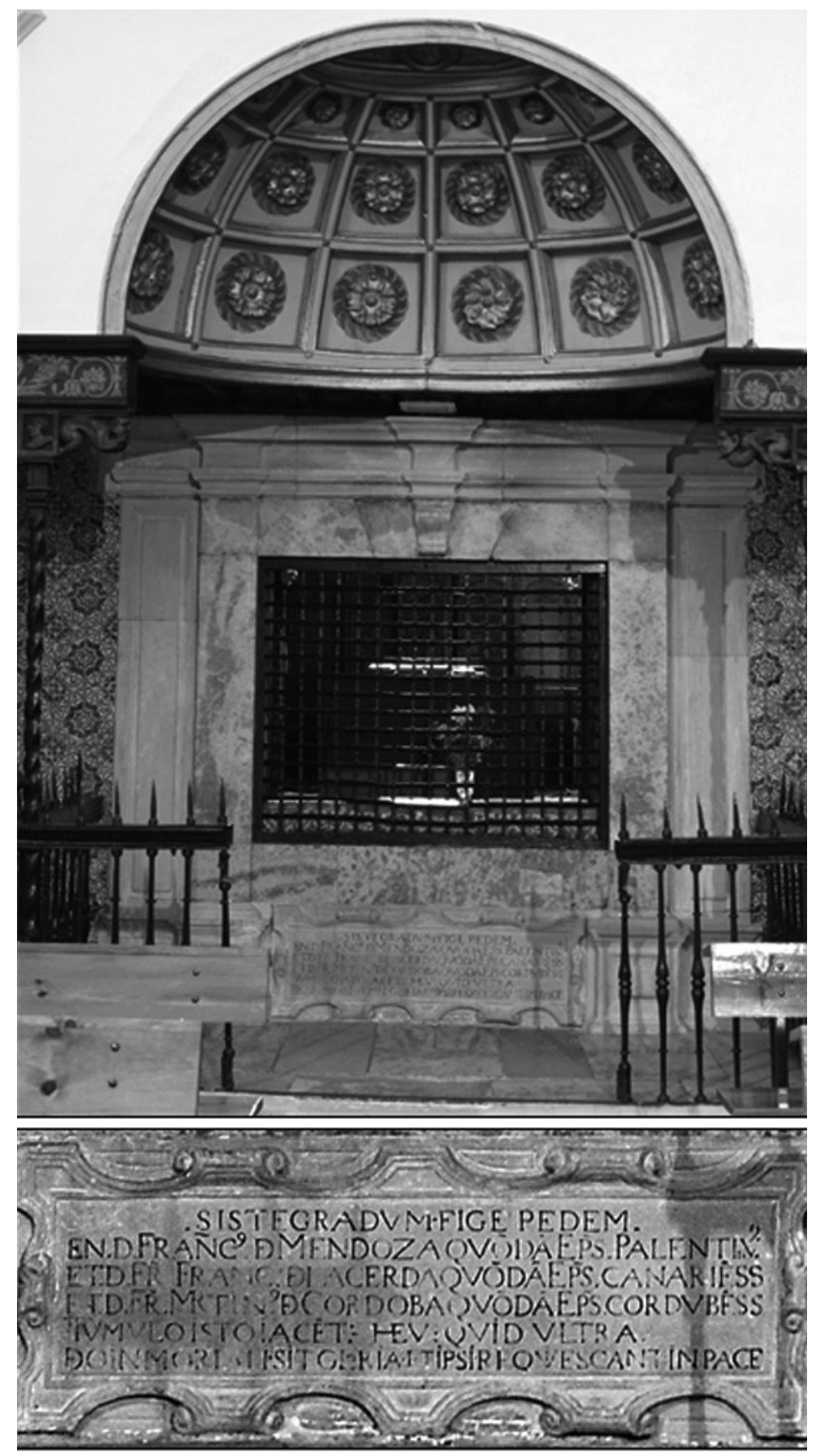

Fotografía: Archivo Diputación de Córdoba. Catálogo Histórico Artístico Provincial, Baena: A320-214.

allí, llegándose incluso a denominar panteón principal de este linaje en múltiples ocasiones. ${ }^{52}$

Así, en el coro, se nos anuncia que fue sepultada bajo la silla prioral, la duquesa doña Francisca Fernández de Córdoba y Castañeda. ${ }^{53}$ Le acompañó en ese mismo sepulcro sor Ana de la Cruz Ponce de León, hija de los marqueses de Priego, que era muda y a quien se le dedicó mucho espacio en la literatura panegirista, ${ }^{54}$ la que sin duda tomó como fuente

52 Fernández de Béthencourt 2003: passim tomos 6 y 7.

53 Francisca Fernández de Córdoba y Castañeda [o de la Cerda], IV duquesa de Sessa y II de Baena, de quien curiosamente no se hace mención en el apartado de 'bienhechores' del Libro de hacienda.

54 López Caparroso 1622: 206r; Lorea Amescua 1681: 187r y Abad de Rute 1954: 181. de información la documentación conventual. ${ }^{55}$ Continúa el libro señalando toda una serie de religiosas que fueron enterradas en el coro, donde se impone su noble ascendencia y relación con el linaje. ${ }^{56} \mathrm{Si}$ bien, de entre ellas destacan doña Ana de Toledo Guzmán y doña Ana de Cardona y Córdoba, hija única y esposa respectivamente del marqués de Ardales. ${ }^{57}$ Madre e hija fueron enterradas bajo la silla prioral del coro, un sepulcro en el que previamente la marquesa se encargó especialmente de hacer enterrar también a sor Francisca Cortés ${ }^{58}$ y sor Catalina Recio 'la santa superiora', ambas consideradas bienaventuradas y prodigiosas santas, y disponiendo que sus cajas estuviesen a la cabeza de las allí sepultadas. ${ }^{59}$ La marquesa doña Ana demuestra así su estatus de preeminencia en el convento $y$, por tanto, repite los mismos parámetros seguidos por la nobleza en el siglo. Y es que pese a no consentir en su entierro ninguna ostentación "sino el trato de la más humilde monja», su caja "se hizo aforrada por dentro en raso blanco y de afuera en terciopelo negro y de raso blanco clabeteada con cintas blancas de Santa Isabel [...] y quatro escudos bordados de las armas de los Guzmanes a las esquinas, que eran del señor marqués por cuya memoria se pusieron $»{ }^{60}$

Por otro lado, la dimensión política del convento se aprecia también en la utilización de su iglesia como lugar de enterramiento de los personajes más destacados de la Casa de Cabra. En otro lugar hemos advertido que a partir del último tercio del siglo XVI los duques de Sessa y Baena prefirieron la villa principal de sus estados como lugar idóneo donde hacer descansar sus restos, y en concreto considerar la capilla mayor de la iglesia del convento Madre de Dios como su panteón, contribuyendo con ello a establecer en este cenobio un espacio donde perpetuar la identidad, el poder y el patrocinio. ${ }^{61}$ De nuevo el libro de los entierros vuelve a ilustrarnos sobre este aspecto de utilización mutua convento-

55 A sor Ana de la Cruz Ponce de León «le faltó el instrumento y lengua para explicar sus conceptos, lo cual hacía con extraordinaria belleza y habilidad por las señas de manos que admiraba...» tomó hábito de devoción en enero de 1602 y profesando en marzo de 1604 enferma in articulo mortis. La dote de 4.000 ducados quedó para la profesión de su criada María de Toro. Libro de profesiones, f. 43v, y Libro de hacienda, f. 213r.

56 Libro de los entierros, f. $9 \mathrm{v}$.

57 Libro de los entierros, ff. 2r-8v y Libro de hacienda, ff. 269r-270v. Doña Ana de Cardona y Córdoba era miembro de la parentela de Cabra, sobrina del III duque de Sessa y I de Baena, y hermana del III duque de Soma. No en balde, bien merece un estudio monográfico la implicación que la marquesa de Ardales tuvo con el convento de Madre de Dios, a la vista de estas informaciones y de la documentación que se conserva tanto en el convento como en los protocolos notariales de Baena.

58 Beata y natural de Lucena, fue animada por la comunidad a profesar en el convento en agosto de 1582, lo que no llegó a formalizarse porque murió a finales de ese mismo año. Libro de profesiones, f. 33v y Libro de hacienda, f. 211v. Se ocupa de glosar su vida López Caparroso 1622: 370v-373v. En el Archivo General del Obispado de Córdoba se encuentra una solicitud de incoación de expediente de canonización promovido por don Martín Cortés y Chacón en 1819. Archivo General Obispado de Córdoba (AGOC). C.6804, D.1 consta solicitud de incoación de expediente de canonización.

59 Archivo Histórico de la Nobleza (AHNOB). C.124, D.63, f. 4v.

60 Ibídem, f. 3v.

61 Una situación que duró poco, dada la tendencia de la nobleza española por establecerse en la corte madrileña, y en concreto por contar la Casa de Cabra-Sessa-Baena desde comienzos del siglo XVII con el patronato de la iglesia del Colegio de Doña María de Aragón. AHNOB. Baena, C.124, D.66. 
nobleza, amén de señalarnos un ejemplo de apropiación de patronato, un fenómeno frecuente en el ámbito de los estados señoriales con los propios señores como protagonistas. En concreto, los $V$ duques de Sessa promovieron desde su embajada cerca de la Santa Sede la compra-apropiación del patronato de la capilla mayor de la iglesia conventual, enviando desde Roma obras de arte y reliquias para su adecuación. Pero convertirse en patronos obligaba trasladar a don Luis, tío del conde fundador y maestresala de los Reyes Católicos y la reina doña Juana, cuyo cuerpo

... solía estar dentro del altar mayor de la iglesia, y por haber comprado para su entierro la dicha capilla los excelentísimos señores duque de Sessa, Soma y Baena don Antonio Folch Fernández de Córdoba y Cardona y mi señora la duquesa doña Juana de Córdoba y Aragón pusieron retablo y altar de piedra, y pasaron el cuerpo del señor don Luis de Córdoba a la capilla del Santo Cristo y está dentro del altar de la dicha capilla y su mujer. ${ }^{62}$

Consiguió el patronato perpetuo de la iglesia conventual la duquesa doña Juana semanas antes de morir, según nos informa la escritura de obligación otorgada con la priora y monjas del convento, previo plácet del maestro provincial de Andalucía:

Se ha concertado el patronazgo privativo e insolidum de la capilla mayor de la iglesia del monasterio de Madre de Dios de la villa de Baena, por lo cual y para los reparos de la dicha capilla mayor la señora duquesa había de dar para después de los días de su vida cuatro mil ducados de principal de un censo [...] impuesto sobre el estado de Baena y Cabra. Tres mil de los cuales para el monasterio en razón del patronazgo y los otros mil ducados para que con los réditos se repare dicha capilla y se compren ornamentos para el culto divino. ${ }^{63}$

La materialización efectiva del patronazgo de la capilla mayor conventual la tenemos tanto en los archivos como físicamente en los entierros del matrimonio ducal y el de su hijo el Príncipe de Maratea, así como en la dotación ornamental de la que hoy sigue haciendo gala este cenobio. ${ }^{64}$

\section{Blasones}

Con el asiento del patronazgo de la capilla mayor de Madre de Dios hemos participado del connatural esfuerzo de la nobleza española por distinguirse del vulgo por medio de enterrar a sus difuntos de manera privilegiada en catedrales, iglesias y monasterios. Pero es necesario algo más. Hay que dejar huella indeleble de la noble ascendencia del allí sepultado, de quién ostenta el patrocinio o quienes costearon tales o cuales objetos de culto u obras de arte para los oficios allí celebrados. Para ello nada mejor que la heráldica.

Ya vimos como el obispo de Palencia dejó patente su intervención en la iglesia conventual con sus armas episcopales; y los duques de Sessa-Baena al convertirse en

\section{Libro de los entierros, f. $11 \mathrm{v}$.}

63 ACMDB, C.2, copia simple de la escritura de obligación suscrita ante Pedro de Comarcada en 1634.07.08, ff. 490r-513r. También en AHNOB. Baena, C.127, D.208.

64 Libro de hacienda, f. 271r. Valverde y Perales 1903: 328-330 transcribe y desarrolla las epigrafías. Por otro lado, don Luis, VI duque de Sessa y IV de Baena, también fue enterrado en Madre de Dios pese a sus intentos de engrandecer el panteón del conde de Cabra en Santa María la Mayor de Baena. Vid Carmona Carmona 2017a.

\section{FIGURA 4}

Conjunto de azulejos de arista sevillanos reaprovechados en el pavimento de la iglesia conventual

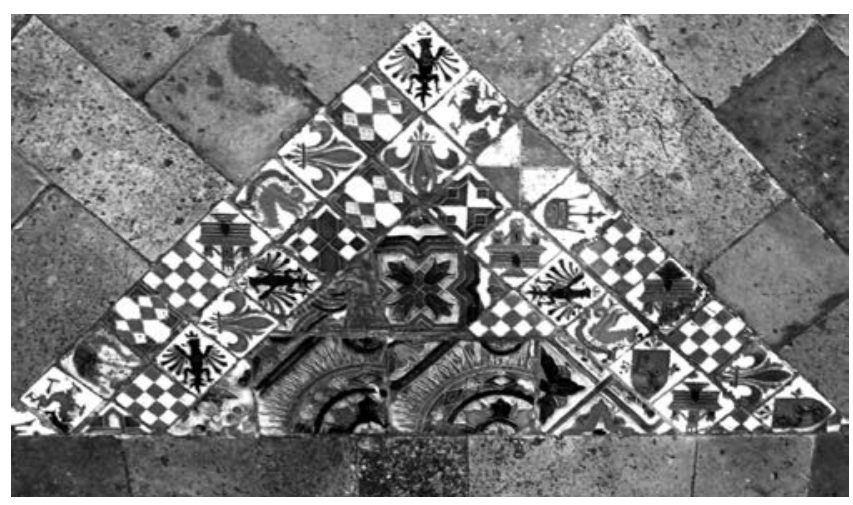

Fotografía del autor.

patronos perpetuos de la capilla mayor también lo hicieron situando sus armas en el plinto que soporta las columnas marmóreas de travertino amarillo que hicieron traer desde Italia para ennoblecer el retablo mayor, como también delimitaron el espacio privativo de la capilla mayor con una magnífica reja donde campean las armas ducales. Y aún hoy, se conservan reaprovechados azulejos sevillanos que a modo de collage forman alfombrillas cerámicas en el pavimento de la iglesia. Se trata de los mismos azulejos que en su día representaban escudos en zócalos, cenefas y frontales, ${ }^{65}$ o que aisladamente con figuras, piezas y fragmentos heráldicos participaban en los alicatados para reforzar el carácter nobiliario de este monasterio ${ }^{66}$ (Fig. 4).

Estos elementos heráldicos son sin duda un ejercicio explícito de autoridad nobiliaria, pues representan el constante y perpetuo recordatorio a la comunidad religiosa allí congregada de qué familias favorecieron su reunión. Refuerzan la idea anterior las armas que campean en las ménsulas sobre las que apean las vigas, recientemente aparecidas en el curso de una restauración del alfarje del coro conventual. Se tratan de los escudos de la orden dominicana y de la Casa de Cabra, únicos que hasta ahora ha señalado la bibliografía, ${ }^{67}$

65 «...se vendieron unos cien [paneles de] azulejos entre ellos seis con escudos» escribía en 1902 al obispo de Córdoba un comisionado informando sobre la venta por parte de la priora de Madre de Dios de 14.000 azulejos del siglo XVI, junto otras obras de arte y objetos litúrgicos, para hacer frente a las reparaciones que precisaba el convento. AGOC. C.6804, D.2, Baena. Obras de reparación en el Convento, correspondencia: 1902.09.20. Como los que tuvo oportunidad de estudiar Balbina Martínez Caviró en el Instituto Valencia de Don Juan con el escudo del III conde de Cabra, los Mendoza y Luna, los Zúñiga y los De la Cerda. Martínez Caviró 1991: 288-290.

66 «Igualmente interesante es la solería formada por pequeños azulejos con motivos variados: el águila, el león rampante, la corona, un ave con vistosas plumas, el ajedrezado, la flor de lis, un escudo con dos iniciales [' $F$ ' e ' $Y$ ' y que nos atrevemos a relacionar con las iniciales de los Reyes Católicos, pues fueron ellos quienes concedieron expresamente gran parte de los señoríos del conde fundador], etc.» (Jordano Barbudo 2002: 551). "Castillos, leones rampantes, flores de lis, estrellas y fajas que tienen un significado, un lenguaje casi perdido hoy en día pero que entonces, fuese o no inteligible para todos, indicaba a las claras algo, en esencia el poder y la respetabilidad de una estirpe.» (Soria Mesa 2011: 7).

67 La suciedad acumulada durante los cinco siglos de existencia de este cenobio solo había permitido distinguir las armas de los condes de Cabra y el escudo de los dominicos en una singular alternancia (Jordano Barbudo 2002: 552). 
FIGURA 5

Blasones que campean en las ménsulas que soportan las vigas del alfarje del coro. De izquierda a derecha y de arriba a abajo: escudo de la Orden de Predicadores, armas del conde de Cabra, del apellido Mendoza, de la Cerda, Zúñiga, Castañeda y Guzmán

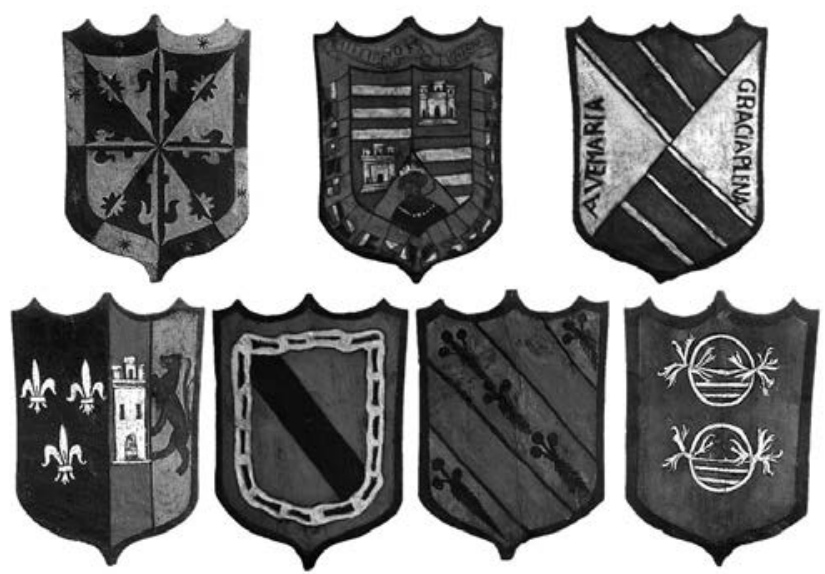

Fotografías gentileza de la Comunidad de RR. MM. Dominicas de Madre de Dios de Baena.

además de otros inéditos pertenecientes a la familia de la condesa fundadora del convento, doña Francisca de Zúñiga y de la Cerda, hija del duque de Béjar (Zúñiga) y de la cuarta señora de Villoria (de la Cerda, Castañeda y Guzmán), más otro que corresponde al apellido Mendoza y Luna, madre del conde fundador. Unas armas que aparecen aisladamente decorando el coro, pero que nos sugieren corresponden a la necesidad de ensalzar el selecto origen de los fundadores. Si atendemos al estilo artístico de la cubierta donde están ubicados, podemos llegar a establecer corresponden a un momento concreto en el que la Casa de Cabra entronca con el ducado de Sessa (Fig. 5).

Al exterior del templo nos encontramos con la misma armería en la portada tardogótica que da acceso a la iglesia conventual: el escudo de la Orden de Predicadores, el del conde de Cabra orlado de las veintidós banderas arrebatadas al rey Boabdil y el escudo de la fundadora, doña Francisca de Zúñiga y de la $\operatorname{Cerda}^{68}$ (Fig. 6). Junto a esta puerta se encuentra otra, hoy cegada, y de la que nos hemos ocupado de relacionar con don Luis, VI duque de Sessa y IV de Baena, y su intención de magnificar la capilla mayor del convento una vez convertido en su patrono. ${ }^{69}$ Se trata de la portada ducal que abriría para adecuarse a los requerimientos ceremoniales y de diferenciación frente al vulgo. El carácter simbólico de la portada reside bajo cada par de pilastras, a ambos lados de la portada, montando sobre un pedestal sendas coronas ducales esculpidas -Sessa y Baena- lo que refuerza la idea de uso privativo de este espacio (Fig. 7). Es el profesor Soria quien nos da noticia de una importante referencia extraída de la tratadística genealógica y nobiliaria de la época, que considera el canon oficial de toda capilla de patronato:

68 De estos escudos se ha ocupado Jordano Barbudo 2012: 493-498.

69 Carmona Carmona 2017c: 106-110.
FIGURA 6

Portada de la iglesia conventual Madre de Dios y detalle

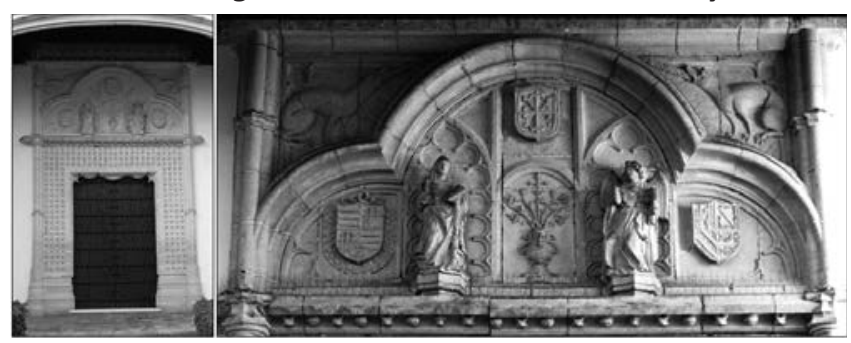

Fotografías del autor.

FIGURA 7

Portada ducal o de acceso a capilla mayor conventual, hoy cegada, mandada realizar por el duque de Sessa y Baena (circa 1636), y detalle del plinto con corona ducal

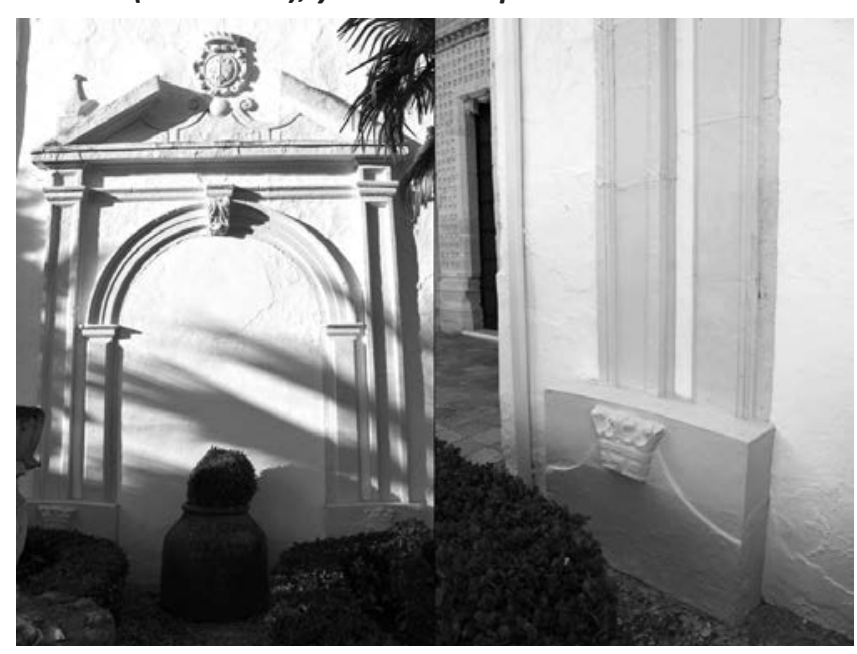

Fotografías del autor.

.. tener puerta, que sale a la calle para poder entrar y salir cuando quisieren los de dicha familia; poseer en dicha capilla magnífico sepulcro, muy elevado del suelo, para descanso de sus cenizas. ${ }^{70}$

\section{Ceremonial}

Asistimos con la adecuación ex profeso de espacios y estructuras conventuales a la participación activa de Madre de Dios en el ceremonial nobiliario desde donde dar visibilidad a la autoridad señorial. Así, el VI duque de Sessa y IV de Baena, pretendió reactivar el protocolo y la dignificación del estatus personal en el gobierno de sus estados. ${ }^{71}$ Tras la muerte de su madre en 1634 y convertirse en patrono de la capilla mayor conventual, no dudaría en aplicar las rentas asignadas para la fábrica de la misma y con ello escenificar una de las cláusulas que estableció en el ceremonial que para el efecto redactó. En él dispone que para su asistencia a los oficios que se celebren en las capillas de su patronazgo (Fig. 8):

70 Soria Mesa 2007: 266, apud Velasco Cevallos: Tabla histórico genealógica de la Casa de Cevallos, manuscrito, 1732, RAH, Colección Salazar y Castro.

71 Carmona Carmona 2017c: 106-110. 
FIGURA 8

Distintas propuestas de ceremonial y precedencias ofrecidas al VI duque de Sessa para los cultos y liturgias en las capillas de su patronato
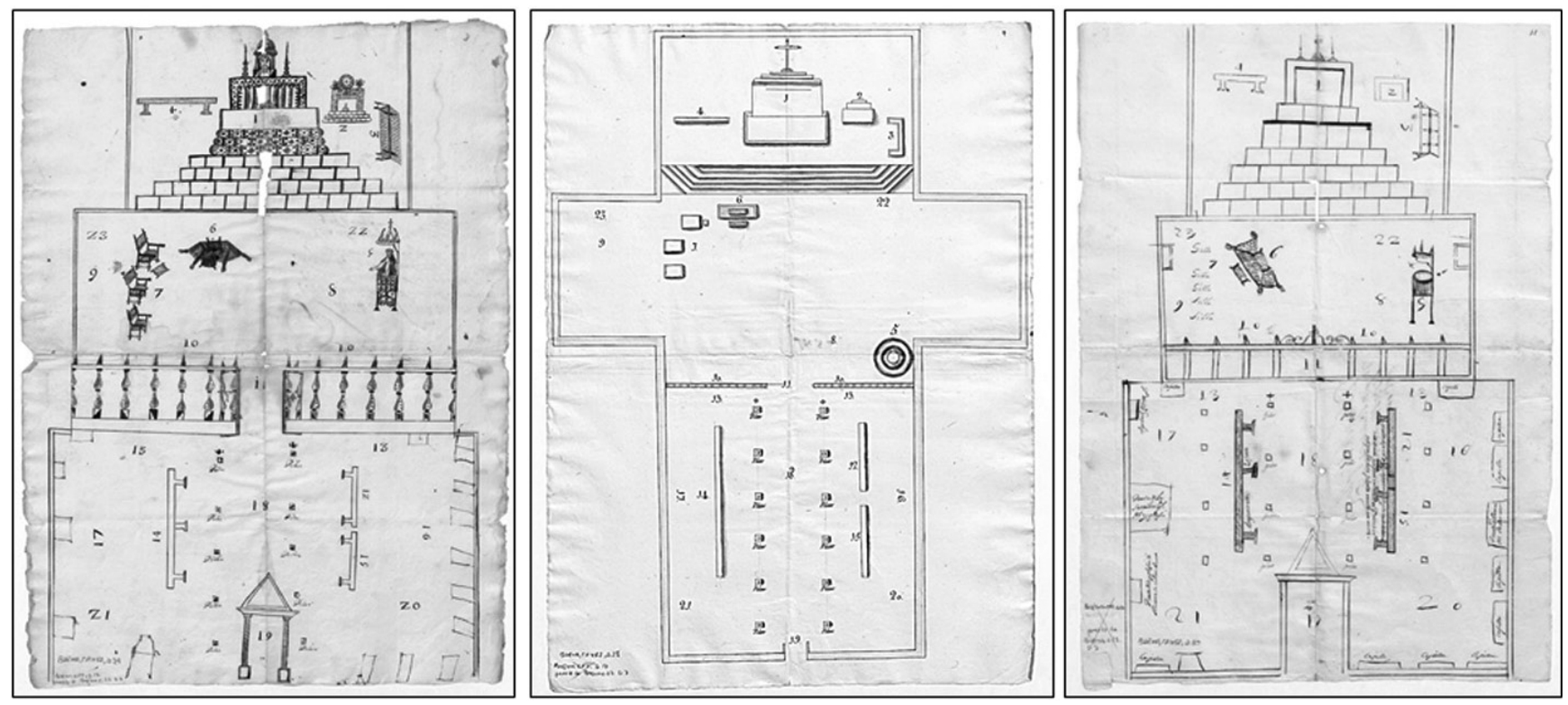

AHNOB. Baena, CP.462, D.27, D.28 y D.30. Planta de la forma en que ha de estar la capilla y los ministros que se sientan en ella, en todos los estados del duque mi sor assi estando en pressa de su exa como en aussa suya. [con distinta tinta y tipo de letra:] Esta es la mas apropossyto y la qe se escogyo (D.27).

... se ha de cerrar la reja, hasta que se entienda que yo entro por la puerta de la iglesia [...] no ha de entrar nadie en la dicha capilla mayor si no fuere la duquesa, nuestros hijos o criados cuando no quisiere estar en la tribuna [...] y las demás personas que nos vinieren desde palacio acompañando, las cuales en dejándonos en nuestro lugar se saldrán luego de la dicha capilla a sus asientos, donde ni por la dicha puerta ni la de la reja se consentirá ni permitirá a nadie meter silla, alfombra, almohada ni otro estrado alguno. Porque en la iglesia y capilla mayor donde están los cuerpos de los señores de esta Casa, ni en la del convento de Madre de Dios, ni se sentarán ni cubrirán sino solamente en el cuerpo de la reja afuera. ${ }^{72}$

Otras manifestaciones ceremoniosas de gran alcance propagandístico promovidas por la estirpe de los condes de Cabra han sido los entierros, convirtiéndose Madre de Dios en escenario privilegiado desde donde reafirmar su condición preeminente. Así tuvo que serlo el depósito y posterior entierro del otro Gran Capitán, Príncipe de Maratea, ${ }^{73}$ quien falleció en Montalbán de Aragón volviendo de Flandes, dejando establecido en su testamento fuese enterrado en el convento de monjas de Baena, de cuyas honras se ocuparon como albaceas su sobrino, el marqués de Belfuerte, y su hermano el duque de Sessa. Por tanto, en un momento de autopromoción personal y significación familiar, aprovechó

72 AHNOB, Baena, C.32, D.9. ff. 12v-13r.

73 Nos da noticia de este personaje, hermano de don Luis, VI duque de Sessa, Fernández de Béthencourt 2003, t.7: 116-117. Por su lado, Lope de Vega lo hace personaje principal de su obra La nueva victoria de don Gonzalo de Córdoba, y cuya significación para con el linaje la ha estudiado Teresa Ferrer Valls, señalándonos cómo Sessa se valió de las comedias de Lope para pergeñar una descarada propaganda de su Casa a través de las gestas de sus familiares y antepasados - como el Gran Capitán o su propio hermano el Príncipe de Maratea- en un momento personal adverso y de marginación en la corte madrileña (Ferrer Valls 2008: 123). don Luis para establecer el ceremonioso itinerario fúnebre desde el convento de Nuestra Señora de Guadalupe, extramuros de la villa de Baena, hasta el convento Madre de Dios, en lo más alto de la Almedina. El cortejo lo encabezaba el conde de Cabra, sobrino del difunto y heredero del ducado, acompañado del corregidor, los priores de los conventos de Guadalupe, de la Consolación de Doña Mencía, de Santo Domingo de Lucena y todos los prohombres de las villas y estados señoriales. ${ }^{74}$ Sin duda un acontecimiento en Baena que no dejaría indiferentes a sus vecinos.

Otra honra fúnebre tuvo lugar en nuestro convento, si cabe esta con más trascendencia por la vinculación del poder nobiliario con lo pretendidamente sagrado. Se trata del ceremonial desarrollado para la marquesa viuda de Ardales, doña Ana de Cardona y Córdoba, un personaje fundamental para Madre de Dios y del que ya nos hemos referido más arriba. De entrada, resulta cuanto menos llamativa la pretendida pobreza con la que deseaba ser sepultada frente a la escenografía en el que fue expuesto su cadáver:

... debajo del dosel que fue del duque mi señor con
sus armas sobre unos bufetes cubiertos de paños negros
se puso el santo cuerpo, y delante del un çetro de plata con
su cruz alta y ciriales [...] estaban abiertas las tres rejas que
ai en el coro, y en la del medio que es la del comulgatorio
y entierro de los señores obispos [...] estaba puesto sobre
una tarima un paño de terciopelo negro pusieron allí a su
excelencia y descubrieronla [...] todo esto se hizo mezclando
la umildad de monja, que no fue el peor adorno, antes lo
que más hiço luçir la grandesa de su excelencia. ${ }^{75}$

El alboroto producido por la muchedumbre que se dio cita en la iglesia conventual para despedirse de la monja-

\footnotetext{
74 AHNOB. Baena, C.124, D.61.

75 AHNOB. Baena, C.124, D.63, f. 4r, 6v. La cursiva es nuestra.
} 
marquesa, obligó a que el corregidor de la villa pusiera orden para sosegar los notables alaridos que profería la plebe y estableciera la prelación entre la afluencia para poder rendirle respetos:

... que biniesen por orden, primero todos los rreligiosos que estaban en la capilla mayor en el coro que les tenían echo. Abia dominicos, franciscos, carmelos y clerigos, algunos de Cabra. Llegaron de dos en dos y con una umilde rreberencia e hincada la rudilla en el suelo llegaron todos a ver a mi señora la marquesa. Tras ellos la gente principal al mismo modo, y todos los demas que pudieron llegar. Duro esto mas de ora y media. ${ }^{76}$

También resultan llamativos los términos ditirámbicos en los que se refiere la anónima autora a la difunta en el memorial, ${ }^{77}$ lo que unido a las exaltaciones como "extraordinaria grandeza de santidad», "su cuerpo santo» o "quedó como una representación de una grandiosísima reliquia», no hacen más que ahondar en un propósito de instigación emocional y dotar de una significación distinta al convento al pretender convertirlo en un contenedor de santidad y ubicarlo en otra esfera de representación.

\section{Reliquias}

El memorial de la muerte y entierro de la marquesa de Ardales nos delata que las honras fúnebres constituyen un original instrumento proveedor de reliquias a Madre de Dios, suscitan el fervor y perpetúan en la memoria colectiva el favor divino que se atesora entre los muros conventuales. Hubo nueva oportunidad en 1654 cuando se le atribuyeron cualidades de santidad a sor Mariana de San José Garzón, y no dudar los duques de Sessa y Baena, que por aquel entonces visitaban sus estados, en sacar provecho y mostrarse piadosos promotores de aquella sacra dimensión. ${ }^{78}$ Pero no fueron estos más que algunos episodios que felizmente alteraron la habitual costumbre en los miembros de la Casa de Cabra de proveer de objetos de devoción a Madre de Dios y así concitar la protección divina.

El ya referido aquí obispo de Ávila, «dio el brazo y reliquia de santa Margarita [a la que se le permitió un culto particular], ${ }^{79}$ la casulla de raso verde rica, imágenes, lienzos y otras muchas cosas sin más obligaciones de encomendarle a Dios». ${ }^{80}$ Mientras que la reliquia de Santa Catalina de Sie-

\footnotetext{
76 Ibídem, ff. 4r-v.

77 Presumiblemente escrito por quien entonces era priora, doña Beatriz de Cristo Cardona, hija natural del III duque de Soma y sobrina de la difunta.

78 Sor Mariana y su hermana sor Francisca de la Cruz entraron en plaza de cantora y organista en 1594 gracias a las gestiones de su tío don Antonio Garzón, racionero de la catedral de Granada. Libro de profesiones, f. 38v. De sor Mariana se refiere Lorea Amescua que a la hora de su muerte «ilustró con esclarecidos testimonios de santidad salió de este siglo. Luego que se supo su dichoso transito fue tan grande el consenso de la gente que en tres días no dieron lugar a enterrarse el cuerpo, nobles y plebeyos pidiendo reliquias de su cuerpo y de su hábito, teniéndose por dichoso, quien podía alcanzarla. Después de tres días difunta quedó en su cuerpo tan tratable que parecía más viva que difunta. Asistieron a sus exequias los excelentísimos señores duques de Sessa, señores de Baena, honrando el señor con su presencia a vista de sus vasallos a sus sierva» (Lorea Amescua 1681: f.192v).

79 ACMDB. C.5, Cartas y licencias, f. $13 \mathrm{r}$ (en adelante Cartas y licencias, sin su localización).

80 Libro de hacienda, f. 269 r.
}

FIGURA 9

Altar de San Jacinto o de las reliquias

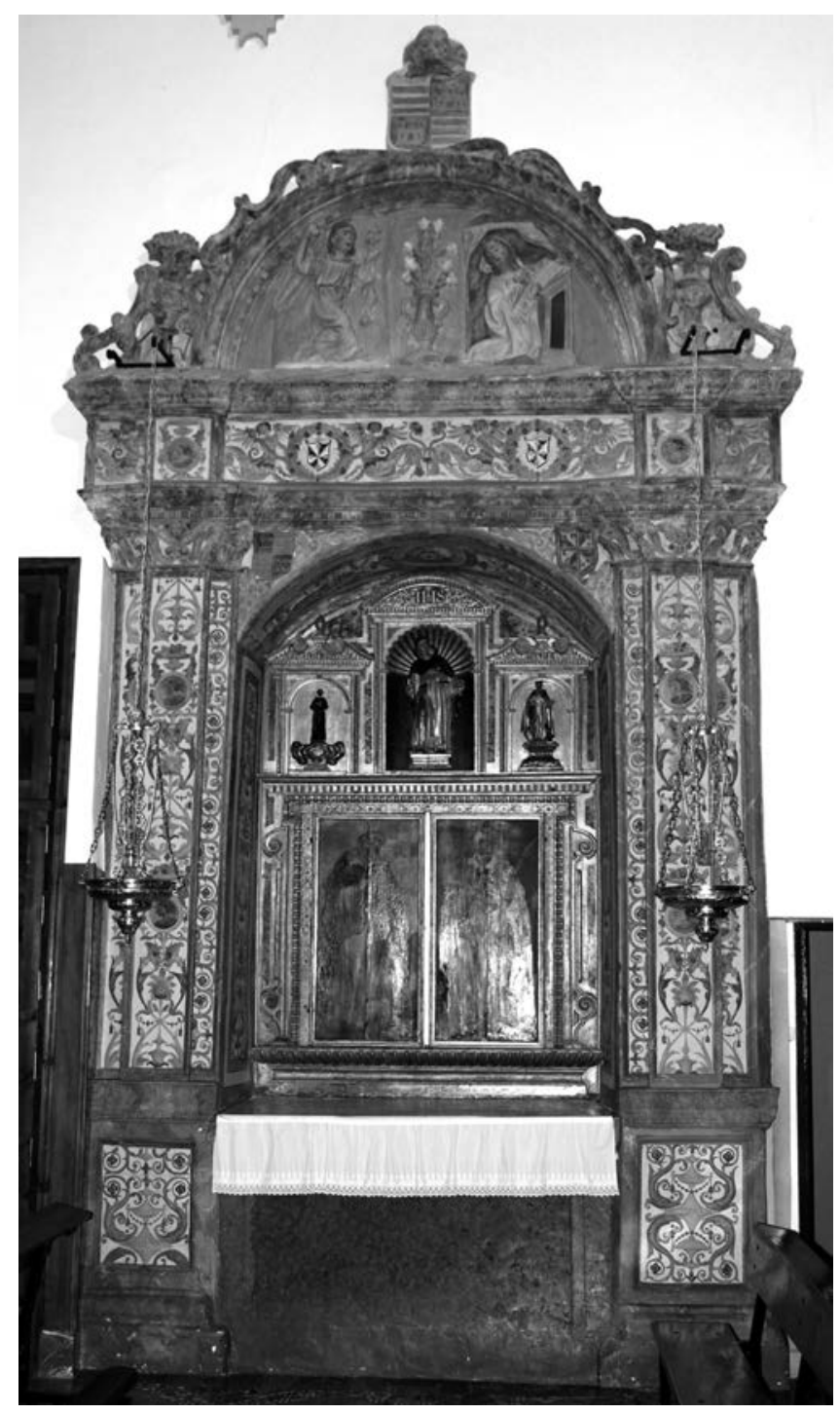

Fotografía del autor.

na fue expresamente «tomada del sancto sepulchro de la dicha sancta en Roma y lo mismo de las otras reliquias» por el maestro general fray Serafín Cavalli para «soror Brianda de Santo Domingo y sus hermanas en el monasterio de nuestra orden en Vaena». ${ }^{81}$ Por su parte, los V duques de Sessa enviaron desde Roma «dos santas espinas de la corona de Nuestro Señor Jesucristo puestas en sus relicarios, dadas a su excelencia de mano de la Santidad de Clemente Octavo, más dos relicarios de Lignun Crucis y otras muchas reliquias en particular de apostoles, mas el traslado del santo sudario y tocado, el verdadero, reliquias del santo pontífice Pio Quinto». ${ }^{82}$

Amparado con el conveniente despliegue heráldico, un retablo-relicario se encargó de custodiar todo ese caudal de santidad que acaparó Madre de Dios durante sus cuatro primeros siglos de existencia ${ }^{83}$ (Fig. 9). Lo que nos habla de un

81 Cartas y licencias, f. 16r, Sevilla, 1566.07.13.

82 Libro de hacienda, f. 271 r y Libro de los entierros, f. 10r.

83 «Junto al coro hay un altar llamado de las reliquias donde se contienen las siguientes: Sagrada Espina de Nuestro Señor, Sábana Tocada a la Sábana Santa, Tierra empapada en leche de la Santísima 
claro afán de sacralizar todo el espacio conventual dotándolo de un simbolismo difícilmente comparable con cualquier otra iglesia de la villa. En definitiva, lo que se pretendió era demostrar la protección divina y la cercanía de este convento con Dios, amén de la identificación que el linaje hacía como favorecedores ante las más altas instancias eclesiásticas y lo que ello redundaba en la concepción de sí mismos.

\section{COMPORTAMIENTOS NOBILIARIOS INTRAMUROS}

Hasta aquí hemos intentado desgranar algunos de los mecanismos por los cuales la Casa de Cabra ha utilizado Madre de Dios para ejercer su política de prestigio en la capital de sus estados. La búsqueda de un enterramiento familiar adecuado, la omnipresente utilización de la heráldica para enfatizar la relación de este cenobio con el linaje que lo propició, la escenografía y el ceremonial desarrollado entre sus muros y los manejos con lo sagrado para reforzar el providencial vínculo nobleza-convento, no hacen sino hablarnos de un instrumento de primer orden para conseguir unos propósitos inherentes al estatus nobiliario. Por su parte, la política de admisión, jerarquización, influencia y cotidianidad de las monjas que lo poblaban bien merecen un análisis detenido, pues nos señalan comportamientos que funcionan como imagen especular de los propiamente nobiliarios.

Desde mediados del XVII asistimos a un progresivo abandono de Madre de Dios como cenobio de referencia por parte del linaje de la Casa de Cabra, y por ende mayor laxitud en las posibilidades de ingreso. No en balde, las tres últimas profesiones con sangre del linaje Fernández de Córdoba son por vía no legítima. ${ }^{84}$ Indudablemente, fijar la Casa ducal su residencia en la corte madrileña, la mengua en el número de miembros que conforman el linaje, y la fundación en 1655 por el $V$ duque de Baena del convento de capuchinas de San Rafael en la ciudad de Córdoba, ${ }^{85}$ hizo reducir paulatinamente la presencia de sangre noble en el convento baenense.

Esta coyuntura propició que los magnates villanos vieran el camino expedito para el ingreso de sus hijas en tan ilustre claustro. Tanto fue así que prohombres de las villas de los estados ducales y limítrofes se lanzaron a ingresar a sus féminas, en ocasiones dos y tres tomas de hábito al unísono, hasta el punto de que en agosto de 1761 obligó al maestro

Virgen, Una zapatilla de San Pio V, Un pedazo de capa de San Luis Beltrán, Una custodia con reliquia de Santa Catalina de Siena y de Santa Teresa, Otra custodia con reliquia de Santa Bárbara, Pequeña reliquia de San Blas y otra de Santo Domingo, Ídem de Santa Úrsula y las Once Mil Vírgenes, Una canilla de Santa Margarita Virgen y Mártir la cual contiene solamente unida a la reliquia la auténtica. La comunidad conserva las auténticas de las antedichas reliquias, más de otras que no existen" (AGOC. C.6806, Descripción del convento, 1914.02.21).

${ }^{84}$ En concreto, doña Juana de Córdoba «hija natural del conde de Torralba [y vizconde de Torres, pariente de los condes de Cabra], quien la crio en su casa y era conocida por su hija, de la que prometió legitimarla», entró siendo aún niña en 1655 y profesó en 1663; y por último entraron en 1667, cuando aún no habían cumplido siete años, Antonia y Luisa de Córdoba, ambas hijas bastardas de don Diego, $V$ marqués de Huétor de Santillán e hijo del VII duque de Sessa, quien tras dos matrimonios murió sin sucesión legítima. Libro de profesiones, ff. $67 \mathrm{r}$ y $69 \mathrm{v}$ respectivamente.

85 AHNOB. Baena, C.273, D.21-56, donde se vuelven a considerar en estos estatutos todos y cada uno de los parámetros aquí tratados. general fray Tomás de Boxadors a prohibir toda toma de hábito y profesión, hasta tanto no se adecuara el número de religiosas a la renta generada por la hacienda conventual. A nuestro entender esta situación de mala administración estuvo provocada por la relativa universalización de los cargos de gobierno conventual en féminas procedentes de la oligarquía villana, quienes primaron lazos de parentesco y de política familiar, tal y como dos siglos antes actuaron las prioras y suprioras Fernández de Córdoba. ${ }^{86}$

\section{Las dotes}

Intentaremos analizar brevemente cómo se ha desarrollado este instrumento de ingreso en el cenobio baenense, habiendo introducido ya los parámetros desde los cuales empezó a gestarse el convento y establecida la necesidad de profesiones provechosas para el mejor gobierno de la fundación. De nuevo el libro de profesiones y el de hacienda ${ }^{87}$ se convierten en los documentos que explícitamente nos manifiestan este aspecto. En Madre de Dios se da un amplio abanico de posibilidades en la dotación para poder formar parte activa en el coro, advirtiendo los libros que una vez aceptada la dote esta es «del convento, aunque se vuelva a su casa cualquiera que tomare el hábito y por justicia se ha determinado que son de la comunidad $॥ .88$

Por lo general, los apuntes de dotes entregadas en metálico terminan con la anotación "echaronse en censo", una fórmula -junto a los juros- con la que proveer al convento de renta estable, pero enormemente sensible a los vaivenes inflacionistas. Así, en 1513 los censos se imponían a diez mil el millar, un 10 \% de interés; en 1562 "hubo baja de hacienda porque se subieron los censos a catorce mil el millar, bajó de diez a catorce porque todos los censos estaban impuesto de diez mil maravedís el millar», aproximadamente un 7,14 \% de rentabilidad; "en el año de 1621 a 8 de octubre se publicó la Pragmática Real en que se subieron los censos de catorce a veinte mil el millar y así se hizo hijuela nueva reducida en ella los censos de a 14 a 20.000 », o lo que es lo mismo un $5 \%$ de interés. ${ }^{89}$ Estas y otras vicisitudes son las que nos permiten analizar

86 En este punto resulta elocuente la carta de Boxadors a la priora sor Ignacia de Jesús Alcalá Galiano: «acerca de la licencia que pide para aceptar la hija de don Francisco María Portillo no puedo venir en concederla pues subsisten en el día en toda su fuerza los motivos que obligaron a dar mi Decreto de Salamanca de 11 de agosto de 1761 en que se prohibe toda acceptacion, vesticion y profession. Por lo relativo a lo que deben pagar las señoritas Balenzuelas que estan es ese nuestro convento a titulo de educación, me admiro que su padre quiere que se passe por $353 \mathrm{r}^{\mathrm{s}} \mathrm{v}^{\mathrm{n}}$ escasos que importan los $129 \mathrm{mrs}$ y que no corresponden a un real al día, con lo que ciertamente ese cavallero no las mantendría en su casa. Y para cortar de una vez essas convenciones tan perjudiciales a los conventos, determino y declaro, que tanto essas señoras si quieren continuar a demorar en esse convento, como qualesquiera otras que por el tiempo quisieren entrar con esse titulo deban contribuir 70 ducados de vellon al año, ni puedan recibirse con menor contribucion [...] Madrid 6 de febrero de 1764» (Cartas y licencias, sin foliar).

87 Las referencias a dotes en el Libro de hacienda se documentan hasta 1646.

88 Libro de profesiones, f. 65r.

89 Libro de hacienda, ff. 283r, 295r-v. Sobre la rentabilidad de la hacienda conventual vid Carmona Carmona 2017b: Anexo 2. Tanteos de renta. 
los incrementos en el valor de las dotes en función de la volatilidad del capital inmovilizado, amén de la bonanza en las cosechas y, lo que más nos interesa, las arbitrariedades en las aceptaciones para integrar el coro.

Así, los 40.000 maravedís establecidos como dotación a poco de iniciada la andadura de este convento pasaron a ser 50.000 a partir de 1527, pero avanzando en el siglo observamos el desigual montante del concepto dote hasta que en la década de 1580 comienzan a homogeneizarse las entradas previo pago de 600 ducados, pero con las irregularidades apuntadas. Esta tendencia al elitismo de sangre y económico provocó que a comienzos del siglo XVII se estableciera una dote de 800 ducados. Pero sin duda el gran detonante para establecer el importe dotacional en 1.000 ducados, aumentado de 100 ducados en ajuar conventual, lo supuso la Real Pragmática de 1621, por la que bajaron los rendimientos de capital al 5 \% y obligó a recomponer la hacienda y a fijar más la atención en ingresos y gastos en las visitas giradas por los provinciales de la orden. No obstante, los 1.100 ducados de dote y ajuar se convirtieron en un importe fijo hasta la invasión napoleónica, si bien se aplicaron nuevos conceptos dotales que encarecieron las profesiones, como la propina o los alimentos. ${ }^{90}$

La lectura atenta de los apuntes dotales nos permite observar la flagrante predilección en la entrada de religiosas de preclara ascendencia, a tenor de lo menguado de su dote respecto a las más recientes profesiones de familias villanas. Es el caso de las dos nietas de don Bernardino de Córdoba, hijo bastardo del conde fundador, quien las dotó a cada una con 450 ducados, cuando venía siendo ya habitual dotar con $600 .{ }^{91}$ También fueron premiadas por su sangre tres sobrinas de don Fernando Carrillo Muñiz de Godoy y Valenzuela (†1622), quienes profesaron cada una con una dote de 700 ducados, y se les «hizo esta gracia por respeto al señor presidente [del Consejo] de Indias, su tío». Una situación que demuestra que la dote era negociada de antemano, justo a la entrada o toma de hábito, es la que señala las profesiones de tres de las cuatro sobrinas Valenzuelas del de Indias. Sor Francisca de San Antonio Valenzuela entró en 1619, junto a su hermana Isabel quien era aún «muy niña», profesando a los catorce meses. Hasta 1627 no lo hizo sor Isabel, señalándose en el mismo apunte los 700 ducados de la profesión "por respeto de su tío» ya difunto. Una prima de estas, sor Catalina de Jesús Valenzuela ingresó en Madre de Dios en 1621, aún en vida de su tío, siendo agraciada con idéntico concierto, algo que no disfrutó su hermana

\footnotetext{
90 A partir de 1650 se aplicó como añadido a la dotación de la nueva profesa la obligación de aportar en concepto de propina un cahíz de trigo o una arroba de cera para la comunidad; por su lado, los alimentos en concepto de manutención desde la entrada en el convento hasta la profesión, fijándose en 12.000 mrs; demostrando nuevamente el libro de profesiones disonancias y arbitrariedades en la aplicación de estas aportaciones.

91 En 1580, sor Leonor y sor Elvira de Córdoba entraron siendo aún muy niñas en el convento, donde ya había tomado hábito de devoción su hermana sor Isabel. Eran hijas de don Diego de Córdoba, de quien Abad de Rute 1954: 397 y Fernández de Béthencourt 2003, t.7: 86 nos lo sitúan en Italia donde contrajo matrimonio. El anonimato de la madre de estas tres sores nos lo despeja el libro de profesiones señalando a doña Libia Sinari (Asinari en libro de hacienda), advirtiendo además de sor Leonor que «es de Lombardía, nació en la ciudad de Alexandria».
}

sor Isabel de San Juan, quien tomó hábito a fines de 1622 y profesando dieciocho meses más tarde, ya difunto su tío, con una dote de 1.100 ducados más 100 de ajuar. ${ }^{92}$

Más arriba hemos mencionado sobre la situación de superpoblación conventual provocada desde finales del siglo XVI hasta 1630, y cómo la lectura interesada del estatuto relativo al número de religiosas que se pueden recibir ocasionó que durante este periodo se arbitrara con más rigor el parámetro discriminador de entrar con crecido dote. Unos comportamientos anómalos, que unidos a la limitación en el número de religiosas, provocan la irremisible inflación en el precio de un sitial en el coro, capaz de afrontarse únicamente por familias adineradas, quienes implícitamente buscaban prestigio social por este alarde munificente y parangonarse con la nobleza. Así lo creyeron conveniente Juan Gómez Roldán asignando a su hija sor María de San Gabriel una dote de 1.000 ducados en 1594, cuando se estaba haciendo por 600; o Luis Pérez de Casarrubias y su esposa doña María de Villalobos, al dotar en 1609 a su hija sor Ana de San Gregorio con 1.200 ducados y 100 de ajuar conventual, ${ }^{93}$ si bien este dispendio pudiera encubrir una intención no tan regalada, a la vista de la solicitud de información sobre la limpieza de sangre años después de la profesión. ${ }^{94}$

Sobre el parámetro dote merece nos detengamos, aunque solo sea brevemente, para apuntar determinados aspectos de las dotaciones gratuitas. Así, a poco de fundado el convento se documentan profesiones gratuitas "por hacerle merced el conde» a la nieta de Pedro Cívico, alguacil mayor de Baena e hija de Martín Clavijo, caballero y criado del conde don Diego. ${ }^{95}$ También hubo espacio para ingresos aparentemente fruto de la devoción, como el caso de sor Bernardina de Quesada, de quien la falta de datos no nos permite sino registrar lo expresado en el apunte de profesión: «no trajo dote por negarse sus padres porque sin su licencia había entrado a ser monja». Estas incorporaciones gratuitas al coro pueden considerarse extraordinarias, cuando la generalidad son en concepto de "tañedora de tecla» u "organista», "en plaza de cantora» o «con condición de que se acabase de mostrar que tenía principios en música», aunque aquí también percibimos una desigual utilización de la gratuidad dependiendo de quién proponga el ingreso, pudiendo concluirse que se trataba más bien de una soterrada utilización de la presentación. ${ }^{96}$

92 Libro de profesiones, ff. 50v, 51r, 52r y 54v; Libro de hacienda, $214 \mathrm{v}-215 \mathrm{v}$.

93 Libro de profesiones, f. 45v.

94 Cartas y licencias, doc. 22. Carta del inquisidor don Gabriel Piçarro [de Hinojosa] que residiendo en Granada çertifica la limpieça de soror Ana de Billalobos para ser monja en $\mathrm{M}^{\mathrm{e}}$ de Dios de Baena, 1615.07.20.

95 Sor Beatriz de Santo Domingo Pineda, profesó en 1528 y «no renunció [a su legítima] ni hubo concierto y fuera del ajuar heredó de su madre $15.000 \mathrm{mrs}$ [1562] y de su tía $215.000 \mathrm{mrs}$ [1578] que para aquellos años fue grande herencia cuando las dotes eran muy moderadas» (Libro de profesiones, f. 13r; Libro de hacienda, f. 209r).

96 Sor Catalina de Santa Ana, hija del doctor Peralta, profesó sin dote como tañedora de tecla en 1576, y a los ocho años lo hizo su hermana sor Victoria de la Magdalena, quien profesó gracias a unos exiguos 400 ducados cuando la dote estaba a 600. El caso ya comentado de las sobrinas de don Antonio Garzón, racionero de la catedral de Granada, entraron sin dote como músicas «por tener el coro gran necesidad de ello», o el de la hija de Pedro Sánchez Blanco, contador 


\section{Las prioras}

Podemos llegar a establecer tres etapas en la utilización del cargo de priora en el convento Madre de Dios de Baena. Un primer periodo de monopolización de las hijas del conde fundador. Le sigue otro atento a las consideraciones de Trento, pero sin llegar a desligarse los cargos conventuales de las féminas Córdobas. Por último, un periodo a partir de la segunda mitad del siglo XVII, con mayor control en las visitas de los provinciales y donde la generalización en la ascendencia señalan directamente al establecimiento de grupos de poder y sagas familiares que aúpan al priorato a una de sus miembros, llegando incluso a la alternancia en los trienios.

Como hemos anunciado, el siglo XVI estuvo acaparado por los prioratos vitalicios de sor Juana de Santo Domingo y Cerda, quien en 1511 el provincial de España fray Alonso de Loaysa, la «puso por priora» pese a su corta edad. El libro de profesiones y el de hacienda vuelven a sernos fuente inestimable sobre este aspecto que se consideró como hereditario, vistos los derroteros del cargo:

Mi señora doña Juana fue priora treinta y siete años poco mas o menos, murió año de [1]546. El dia que este convento se fundo entro a ser monja mi señora doña Brianda, hija del conde mi señor, no se le dio el habito por ser niña de ocho años, fue priora veinte años después de mi señora doña Juana. Murio a veintytres de febrero de 1567. En setiembre de [1]523 años hizo profesión la señora Ana del Espiritu Santo, hija del conde mi señor [...] fue priora por seis años y murió en setiembre de [1]573. ${ }^{97}$

Acabado el priorato sucesorio de las tres hijas legítimas del conde fundador, le cupo la oportunidad a sor Leonor de Cristo, su hija bastarda, que pudo ocupar la silla prioral en este fenómeno que podríamos llegar a homologar a un mayorazgo intramuros. Máxime cuando nada contraviene a los decretos trentinos sobre la renovación de cargos, y en el caso concreto de Madre de Dios, en una visita del maestro general de la orden fray Sixto Fabio de Luca (1583-1589) dispone que:

... hallando costumbre en el desde su fundaçion de reelegirse las madres prioras acabados sus tres años por liçençia que an tenido de los $r^{\text {mos }}$ generales nuestros predeçesores y hallando por esperiençia ser en este venerable monasterio útil y provechoso la tal reeleçion ansi en lo espiritual como en lo temporal [...] les confirmo las liçençias sobre esto dadas y de nuevo se las conçedo para que cada y quando que ubiera acabado su ofiçio la madre pryora que ora es o las que de aquí adelante fueren puedan si quisieren tornarlas a reelegir dexando en su libertad a las religiosas para que si no les pareçiere reelegir a la que acabo puedan elegir la que mas conviniere al servicio de $\mathrm{N}^{\text {ro }} \mathrm{S}^{\mathrm{r}}$ y bien de la casa. ${ }^{98}$

Por esta licencia sor Leonor de Cristo (†1601) fue priora durante doce años, tras los cuales ayudó como supriora en el priorato de sor Mencía de la Madre de Dios, otra Córdoba

del duque de Arcos, quien profesó en 1698 como organista sin dote, pero con ajuar personal y 9 arrobas de cera para la comunidad. Estos y otros son algunos ejemplos que podemos llegar a extraer del Libro de profesiones.

97 Libro de profesiones, ff. $3 \mathrm{v}-4 \mathrm{r}$.

98 Cartas y licencias, f. 17. Licencia del IImo. General para poder reelegir a las $\mathrm{mm}$ prioras. Baena, 1588.12 .12 en los cargos de gobierno, pues era prima hermana del conde de Cabra. ${ }^{99}$

Durante la primera mitad del siglo XVII asistimos a la que hemos establecido como segunda etapa en la excelencia de sangre prioral de Madre de Dios, cuando fallecidas las hijas del fundador hay que acudir a otros grados de parentesco u oportunidad política. En este periodo ostentaron el cargo un grupo de religiosas que, de un modo u otro, se vinculan consanguíneamente con el fundador o mantienen con el linaje una relación clientelar. Es el caso de sor Beatriz de San Miguel Cabrera (†1606) quien era hija de Jerónimo de Valenzuela, caballero principal de la Casa del conde, ${ }^{100}$ documentada como priora a punto de acabar el siglo XVI. Le sucedió en el cargo una sobrina del conde fundador, sor Francisca de Jesús Mendoza (†1619), nieta del obispo de Palencia. ${ }^{101}$

Con sor Beatriz de Cristo Cardona, ${ }^{102}$ priora entre 1601 y 1609 , hubo que pedir dispensa apostólica para que el convento la pudiese elegir por no tener los cuarenta años de edad exigidos por Trento, ${ }^{103}$ debiendo pesar en la decisión el tratarse de la sobrina del duque de Sessa, cabeza de linaje de Cabra. La dotó su tío Antonio con 1.000 ducados, pagando el día de su profesión 500 y «los otros 500 los dará cuando su excelencia herede el estado de Baena». Su priorato coincidió con los últimos años de la embajada del duque en Roma, cuando ya existen referencias documentales del deseo de convertir la capilla mayor conventual en patronato ducal, advirtiéndose el motivo de la premura en tener una priora presta a la causa. Nuevamente fue priora en 1624 y acabado su trienio se consiguió otra bula «para que el convento de Madre de Dios de Baena pudiera reelegir por priora el trienio siguiente por el bien que de ello resultaría y mucho provecho». ${ }^{104}$ En marzo de 1644 falleció esta señora cuando ejercía otra vez oficio de priora.

En el entretanto de los prioratos de doña Beatriz se sucedieron los de sor Francisca de Madre de Dios Reinoso

99 Mencía de Guzmán (†1599), era hija de don Luis Fernández de Córdoba, tío del conde fundador y maestresala de los Reyes Católicos y su hija Juana, y de doña Constanza de Rivera y Guzmán. A esta priora se loa en los libros como «de las monjas mas sustanciales que ha tenido la religión, ejemplo de priora y muy fina Guzman, porque fue muy hija de $\mathrm{N}^{\text {tro }} \mathrm{P}^{\mathrm{e}}$ en el apellido y costumbre». Libro de profesiones, f. 8v; Libro de hacienda, f. 208v; Abad de Rute 1953: 289.

100 Valenzuela es «apellido de notoria nobleza» íntimamente ligado a la Casa de Cabra. Prueba de ello son las dos capillas de Pedro de Valenzuela que flanquean la mayor -de fundación condal- en la cabecera de la parroquial de Santa María la Mayor de Baena. AHNOB. Baena, C.23, D.7.

101 A sor Francisca de Jesús Mendoza, hija de don Pedro Ponce de León y de doña Isabel de Mendoza y Córdoba, sobrina por tanto del obispo de Ávila ya referido, la hacemos aquí costeadora del altar de San Jacinto, luego convertido en altar-relicario. El estudio detenido del blasón que corona el tímpano lo hace indudablemente armas de los Mesía Carrillo, señores de la Guardia y Santofimia; amén que el libro de hacienda nos delata a esta priora como «devotísima de San Jacinto a quien hizo altar, figura de talla y fiesta» (Libro de hacienda, f. 209v).

102 Doña Beatriz de Cardona entró en Madre de Dios en abril de 1573 a la edad de 5 años. Fue hija natural de don Luis de Cardona y Córdoba, III duque de Soma y conde de Oliveto, quien murió soltero en Nápoles en marzo de 1574.

103 «La abadesa y priora [...] se ha de elegir de no menos edad que de cuarenta años, debiendo haber vivido loablemente ocho años después de haber hecho su profesión» (Concilio de Trento 1798: 367 y 371).

104 AHNOB. Baena, C.273, D.15-17. 
quien, junto a su hermana sor Juana Evangelista, salió en 1600 para ser priora fundadora del convento de Santa Ana de Lucena, siendo obsequiada a su regreso con la silla prioral. Bisnieta bastarda del conde fundador fue sor Isabel de la Concepción y Córdoba la que también fue priora en 1618, y su hermana Leonor la sucedió en el cargo tras el segundo periodo prioral de la hija del duque de Soma; y una tercera hermana, sor Elvira, en un incierto periodo durante dos prioratos; como lo es también el priorato de sor Elvira de Córdoba, hija del marqués de Priego. Por último, con sor Isabel de Morales finaliza el periodo de sores tocadas por la dignidad o la gracia del linaje de los Córdobas, documentada priora en 1632 debió estar por su ascendencia muy cercana a los favores ducales, pues en 1593 la dotó con 500 ducados el de Sessa y Baena. ${ }^{105}$

A partir de mediados del siglo XVII consideramos el tercer estadio en la utilización del cargo de priora. Un periodo donde los libros guardan un relativo mutismo acerca de los periodos en los que se ejerce, tan solo se extraen vagas consideraciones de cuántos trienios la religiosa ocupó la silla prioral. Lo que sí deja claro el de profesiones es que, hasta acabar el siglo XVII, si el coro lo forma una religiosa de noble ascendencia o de familia hidalga de la villa, a esta se la referirá con una simple anotación como priora en varias elecciones. Como los tres trienios que desempeñó como priora sor Elvira de la Cruz, natural de Puente Genil y hermana del caballero de la Orden de Alcántara don José de Aranda; o los otros tres prioratos de sor Manuela del Espíritu Santo, hija del jurado Luis Bernardo; o los cuatro cargos que desarrolló sor Margarita de los Reyes, quien ingresó en 1674 con cinco años de edad, junto a su hermana Francisca, de cuatro. A partir de aquí, solo conocemos la identidad de algunas prioras por fuentes indirectas, por ser destinatarias de diversa correspondencia remitida por los padres generales o provinciales. ${ }^{106}$

\section{Sagas familiares}

Hemos asistido a cómo las féminas del linaje de la Casa de Cabra se fueron desempeñando en el cargo de priora cual línea sucesoria, estableciendo claramente unos criterios decisorios en favor de la política familiar. Si bien, fruto del decaimiento de este elitismo nobiliario a partir de mediados del siglo XVII y el establecimiento de una dote fija y concreta, comparable en términos relativos a cualquier otro convento femenino de la orden, favoreció que las familias adineradas lograran ingresar a sus hijas en Madre de Dios. Con ello se produjo en nuestro convento una universalización demográfica que en rasgos generales no difiere de estructuras precedentes. Así, el libro de profesiones nos muestra numerosos casos en los que una familia ingresa en un único acto al orden de dos a cuatro hijas, algunas de ellas de cortísima edad. Lo que a priori no supone más que la aceptación de ciertas educandas con una asignación alimentaria determinada, se está favoreciendo a la postre formar un grupo de presión y opinión. A esto ayuda la laxitud en observar las reglas de la orden, habida cuenta

\footnotetext{
105 AHNOB. Baena, C.12, D.5, ff. 25v-26v.

106 Libro de profesiones, ff. 59r, 66v y 70r.
}

del poco rigor en la vida comunitaria, lo que abocaría a no pocos conflictos y divergencias en determinados asuntos de trámite, entre ellos la aceptación de tal o cual religiosa dependiendo -nuevamente- de su ascendencia. No preocupaba tanto la dimensión demográfica conventual que acontecía para mediados del siglo XVIII -hecho generalizado en la Segunda Orden Dominica- y que concluiría con la decisión de fray Tomás de Boxadors de prohibir poder aceptar a más religiosas en los conventos hasta lograrse la sintonía entre población y renta.

En este contexto encontramos entre otros muchos a Alonso Zejalbo, vecino de Alcalá la Real, quienes ingresaron al unísono a Laurencia, Ana y Josefa, muriendo las dos primeras al poco tiempo de profesas. Parecido es el caso de las Quirogas, que en 1721 tomaron el hábito juntas Ana y Juana y a los pocos años Josefa. O las tres hijas de Diego Guerrero y doña Francisca de Berrio. ${ }^{107}$ Llamativo es el caso de Catalina y Ana de Medinilla, esta última bebé de 18 meses de edad, quienes ingresaron en 1665 para regresarse con sus padres a los dos años por la poca salud de Catalina. No cejaron los padres en lograr tener a sus hijas en Madre de Dios, pues a mediados de 1670 volvieron a ingresar a Ana, que contaba ya con 8 años, junto a su hermana Mónica también de corta edad. ${ }^{108}$

\section{Convento-hospital-hospedería-escuela}

Acudiendo de nuevo al concepto de salvaguarda del honor familiar a través de sus miembros femeninos, viene siendo notoria la utilización accesoria del convento como locus ideal para el adoctrinamiento en la fe y la educación de las infantas de la nobleza por parte de la comunidad. Para delatarlo vuelve a servirnos de fuente principal el libro de profesiones, descubriéndonos además el apunte de miembros femeninos de la alta nobleza que residen durante un corto periodo de tiempo en el convento, y que sin tomar estado religioso se asientan dándonos todo tipo de detalles de su filiación y destino. Una práctica que interpretamos como necesaria en el memorial insigne de este convento. Otros datos nos señalan el convencimiento de las nobles familias de que en el convento es donde mejor van a mitigar o curar las dolencias de sus hijas, vislumbrándose en algunos casos más bien un trasfondo de reclusión.

El caso arriba aludido de sor Ana de Medinilla, a la que hicieron ingresar con escaso año y medio de vida, es un extremo entre tanta obviedad. Lo habitual fue la entrada de niñas de muy corta edad cuyo destino estaba delimitado entre los altos muros conventuales o, en el mejor de los casos, a la espera que se determinase qué estado había de tomar. Las niñas se criaban e instruían en el convento en calidad de educandas a cambio del pago de sus alimentos hasta que cumplían doce años, momento en el que se las interrogaba sobre su inclinación a tomar el hábito de devoción. Es lo que le ocurrió a sor Dominica de San

107 Libro de profesiones, ff. 76v-77r, 81v y 83r-v.

108 Hijas del caballero calatravo don Sebastián de Medinilla, vecino de Cabra. Catalina ingresó con 10 años y de Ana María el libro de profesiones se refiere: «por ser tan pequeña se minoraron algo los alimentos hasta que cumpla 6 años que los han de dar por enteros» (Libro de profesiones, ff. 68v-69r). 
Francisco, hija natural del marqués de Ardales, quien salió con temprana edad del convento «a casarse y tardose en el mundo diez años. Después tuvo devoción de ser monja en las [carmelitas] descalzas de Cabra y allí lo es y ya profesa». ${ }^{109}$ Si bien de todo ello adivinamos una maniobra orquestada por la poderosa marquesa de Ardales, quien no vería con buenos ojos que una hija bastarda de su esposo conviviera con su hija legítima, que se criaba en el convento como educanda.

Advertida la ocupación accesoria de Madre de Dios para el cuidado y honra de niñas nobles, resulta cuanto menos llamativo que en su libro de profesiones se incluya la presencia de hijas de miembros de la alta nobleza española cuando no han tomado estado religioso en él, ni se indica dote ni pago de alimento. Destacado fue sin duda el paso de las dos hijas del caballerizo mayor del rey Felipe II, don Diego Fernández de Córdoba, de quien su estrecho trato con el monarca obligaría a dejar referencia explícita de la presencia de estas destacadas señoras en este monasterio. ${ }^{110}$ Doña Ana María y doña Margarita casos extraordinarios en la utilización del tratamiento 'doña' en los libros conventuales- ingresaron ambas a finales de 1576, gracias a su tío el obispo de Córdoba, don Francisco Pacheco, quien «las dio a criar siendo muy niñas en el convento de Baena». ${ }^{111}$ Doña Ana María «al tiempo de profesar le pareció al señor obispo casarla» con el heredero del señor de Guadalcázar; doña Margarita «tampoco hizo profesión porque su hermano el marqués [de El Carpio] la llevó a Jesús Crucificado y allí murió». ${ }^{112}$ Tal vez, en la confianza de contar con tan principales doncellas en el coro y verse frustradas las pretensiones, provocó el mandato del general Cavalli por el que prohíbe recibir «monjas profesas en otros monasterios, ni las que de este una vez salieren, vuelvan despues a él si no siendo por título de reformación o de fundación». ${ }^{113}$

Numerosas fueron también las monjas que salieron de la clausura por su poca salud en distintos momentos de su vida religiosa, del mismo modo que los libros se refieren profusamente a las enfermedades y el tiempo que las padecieron antes de su muerte en un alarde de justificación de su fe. Lo cierto es que la enfermería debió estar tremendamente concurrida, a la vista de los apuntes vertidos sobre este aspecto en el libro de profesiones; si bien, de todo este concurso de sores nos interesa entresacar la utilización del convento como sanatorio por parte de la nobleza. Sin duda alguna, enorme gratitud debió tener la Casa de Cabra para con la aya de sus menores, pues al final de sus días ingresó en Madre de Dios y a los pocos meses profesó «cuando estaba enferma de muerte en la cama». Nada extraño tiene, a la vista de las informaciones

109 Libro de profesiones, f. 36r. A ella se refiere el marqués en su testamento. AHPCO. C.90P.

110 Don Diego, IV señor de Armunia, caballerizo mayor del rey Felipe II, comendador mayor de la Orden de Calatrava, era nieto por línea materna del conde fundador de Madre de Dios. La familiaridad con el rey la pone en evidencia Bouza 2008: 94-95; así como Kusche Zettelmeyer 1991: 7 al señalarnos a don Diego y al marqués de El Carpio, don Luis Méndez de Haro, como los dos únicos retratados no regios en ocupar un lugar en la galería de retratos del Pardo.

111 Fernández de Béthencourt 2003, t.6: 124-125.

112 Libro de profesiones, f. 29v.

113 Cartas y licencias, f. 11r. conventuales, el tomar velo negro en articulo mortis, pues supone una escala más alta en la santificación del alma. Así se entendió cuando enferma de muerte profesó sor Ana de la Cruz, hija de los marqueses de Priego; como también en 1616 pidió le impusieran el velo negro la marquesa de Ardales, aunque se «restableció de su enfermedad mortal». En un afán de emulación, Ana de Albanella, criada de la de Ardales, a quien le prometió dotarla pero «por los pleitos que la marquesa ha traído, se dilató la profesión de esta madre» consiguiéndolo tardíamente seis días antes de su muerte. ${ }^{114}$

\section{CONCLUSIÓN}

Hasta aquí el intento de desgranar algunos de los aspectos más relevantes de los que se valieron los miembros del linaje de la Casa de Cabra para dar a conocer su preeminencia política, económica y social en sus estados a través de parámetros visuales y ceremoniosos. Del mismo modo que también lo hicieron reflejar y proyectar sus mujeres entre los muros conventuales.

Hemos aludido al papel que la mujer ha ejercido entre los muros monacales en favor de las estratégicas redes políticas, económicas y clientelares de la familia, y que ha quedado suficientemente evidenciado en el caso de las féminas Córdobas en su vinculación con el convento baenense. Se ha dado a conocer el inédito beaterio que llegaría a incorporarse al cenobio; el paso por su claustro de ilustres hijas de la nobleza hispánica; así como a algunas de las miembros ilegítimas de esta parentela, que silenciadas o desconocidas por los estudios genealógicos, encontraron en Madre de Dios el mejor acomodo para estas hijas bastardas. Además, se ha señalado la utilización de la heráldica en el seno de la comunidad por su carácter distintivo, y se ha dado luz a los desconocidos blasones que campean en el alfarje del coro conventual con la heráldica del matrimonio condal fundador. También se han documentado los desvelos ceremoniosos de los duques de Sessa, que dejaron huella en la capilla mayor de la iglesia conventual.

Por otro lado, el archivo conventual nos muestra unos comportamientos internos fieles a los propiamente nobiliarios en el siglo. Ha quedado demostrada la utilización de una estricta línea sucesoria en el cargo de priora durante su primer siglo y medio de existencia, amén de haber dado a conocer la discrecionalidad en la exigencia y cuantía de la dote de profesión en favor de deudos o la clientela, así como la proliferación de sagas familiares que determinarían la demografía conventual y, en última instancia, su observancia.

Pero si sobre cualquier otro aspecto algo hemos querido destacar es la importancia que poseen los archivos conventuales. Una fuente de primer orden para la Antropología y los estudios de género tan demandados en la actualidad, para los estudios genealógicos y la Historia social, económica, de la Iglesia o las propias órdenes que los originaron. De todo ello el convento de Madre de Dios de Baena es buena muestra, y su archivo así lo corrobora.

\footnotetext{
114 Libro de profesiones, ff. 21r, 43v, 46r-v, 47v.
} 


\section{FUENTES MANUSCRITAS Y DOCUMENTALES}

ACMDB - Archivo Conventual Madre de Dios de Baena

Cartas y licencias

Caja 5. Cuaderno que contiene cartas y licencias de nuestros reverendísimos padres maestros generales, [1551-1764].

Entierro del Príncipe de Maratea

Caja 2. Consulta de tres padres Maestros del Real convento de San Pablo de Córdoba en orden a entrar unos caballeros en la clausura a depositar los huesos del Señor Don Gonzalo de Córdoba [...], sin fecha.

Estatutos y letras apostólicas

Caja 2. Cuaderno de transsumptos de estatutos de este Convento de Madre de Dios de Vaena y de letras apostolicas y de Nuestros Reverendísimos Padres Generales con algunas declaraciones... Fotocopia de un manuscrito perdido de 1630, 42 folios. Se trata de la transcripción y perfección jurídica a la recopilación documenta promovida por el Maestro fray Juan de los Ángeles, prior provincial de la Provincial dominicana de Andalucía entre 1628-1632.

Libro de hacienda

Caja 1. Libro de la hazienda que este convento de Madre de Dios tiene y de los papeles de más consideración que en su archivo están con sus tablas para más declaración... Manuscrito, comenzado en 1620 y encuadernado en 1793.

Libro de los entierros

Caja 4. Libro de los entierros que hay en el coro y en la iglesia de los señores de esta casa. Manuscrito, s/f, 12 folios cosidos formando contraportada del Libro de profesiones.

Libro de profesiones

Caja 4. Libro de las profesiones de las monjas de Madre de Dios de Baena y de los entierros que hay en el coro y en la iglesia de los señores de esta casa. Manuscrito, 1598-1877 [donde se trascribe el denominado 'Libro viejo' (ca. 1511-1598) hasta la última anotación en 1877].

Testamento de doña María Carrillo [de Córdoba, sor María de San Gabriel]

Caja 3. Testamento otorgado por la Muy llustre Señora $D^{\underline{a}}$ María Carrillo antes de su profesión, 1526.11.06, ante Gonzalo de Pareja, escribano público de Baena.

Testamento del obispo de Ávila

Caja 2. Testamento del Ilustrísimo Señor Don Diego de Córdoba, abad de Castrogeriz, obispo electo de Ávila, dado en Castrogeriz a 1558.12.05 ante Hernán Rodríguez, teniente corregidor de la villa.

Testamento del obispo de Palencia

Caja 1. Pleito sobre el testamento de don Francisco de Córdoba, obispo de Palencia, ante el escribano público Pedro Gutiérrez: Escritura por la qual se dio por libre el deposito que en este convento se avia echo de los ornamentos y alajas que dejo para su capilla el señor obispo..., 1558. Donde se transcribe su testamento, dado en Madrid en 1536.01.17 en ff. 11v-30r.

AFNSR - Archivo de la Federación Nuestra Señora del Rosario de Madres Dominicas

Cajón 4, Libro 2, Convento de Jesús Crucificado. Libro de consultas [1674-1820].

Cajón 10, Libro 3, Convento Santa María de Gracia. Libro de gastos de funeral desde 1770 [hasta 1834].

AGOC - Archivo General Obispado de Córdoba, Órdenes Religiosas Femeninas

Caja 6.806. Baena, Convento Madre de Dios.

AHNOB - Archivo Histórico de la Nobleza, Fondo Baena

Caja 12, Documento 5. Reconocimiento y obligación que se haze al monasterio de la Madre de Dios de Baena de los 500 ducados por doña Isabel del Espiritu Santo.
Caja 23, Documento 7. Capillas de la iglesia de Santa María [la Mayor] de Baena.

Caja 124, Documento 63. Fe de muerte. Relación de la muerte y entierro de la Sra Marquesa de Ardales Da Ana de Cardona y Cordova, en el Monasterio de Monjas de la Madre de Dios de Baena. Falleció en 7 de julio de 1624.

Caja 124, Documento 61. Depósito y traslación del cuerpo de Don Gonzalo Fernández de Córdoba, Príncipe que fue de Maratea hecha en la tribunilla del coro del convento de Dominicas de la $\mathrm{V}^{\mathrm{a}}$ de Vaena á instancia de sus testamentarios en 20 de julio de 1636 ante Pedro Gomez Moreno, es ${ }^{\text {no }}$ pub ${ }^{c o}$.

Caja 273, Documentos 21-56. Patronato de las capuchinas de San Rafael de la ciudad de Córdoba hecho por don Antonio Fernández de Córdoba, [V] duque de Baena y [VII] Sessa. 1655.09.24.

Caja 273, Documentos 15-17. Bula del Nuncio Apostólico [...] para que diese licencia a las monjas del convento de la Madre de Dios de la Villa de Baena, del mismo orden, para que pudiesen reelegir por su Priora, el trienio siguiente a Soror Beatriz de Cardona [...] Madrid, 1628.06.10.

AHPCO - Archivo Histórico Provincial de Córdoba, Distrito Baena

Caja 70P. Cobro de la dote de sor Teresa de Jesús Cabrera, ff. 21r-26r. 1590.06.04.

Caja 90P. Testamento de don Juan Ramírez de Guzmán, marqués de Ardales y conde de Teba, ff. 656r-687v. 1607.11.10.

Caja 91P. Poder dado por doña Ana de Cardona, marquesa viuda de Ardales, para reclamar la mala venta de los bienes del Capitán General de Orán, su marido, ff. 20v-23r. 1608.01.15.

\section{BIBLIOGRAFÍA}

Abad de Rute, fray F. Fernández de Córdoba. 1954. Historia y descripción de la antigüedad y descendencia de la Casa de Córdoba. Córdoba: Real Academia.

Alegre Carvajal, E. 2004. Las villas ducales como tipología urbana. Madrid: UNED.

Atienza López, Á. 2008. Tiempos de conventos. Una historia social de las fundaciones en la España moderna. Madrid: Marcial PonsUniversidad de La Rioja.

Atienza López, Á. 2010. «Nobleza, poder señorial y conventos en la España Moderna. La dimensión política de las fundaciones nobiliarias», en E. Sarasa Sánchez y E. Serrano Martín (coords.), Estudios sobre señorío y feudalismo: Homenaje a Julio Valdeón: 235-269. Zaragoza: Institución Fernando El Católico.

Atienza López, Á. 2012. «El mundo de las monjas y de los claustros femeninos en la Edad Moderna. Perspectivas recientes y algunos retos», en E. Serrano Martín (coord.), De la tierra al Cielo: Líneas recientes de investigación en Historia Moderna: 89-108. Zaragoza: Institución Fernando El Católico.

Barrio Gozalo, M. 2010. El clero en la España moderna. Córdoba: CSICCajasur.

Bouza, F. 2008. Cartas de Felipe II a sus hijas. Madrid: Akal.

Carmona Carmona, F. M. 2017a. «El frustrado proyecto para panteón y sepulcro del duque de Sessa en Baena». Archivo Español de Arte 90 (357): 19-30. https://doi.org/10.3989/aearte.2017.02

Carmona Carmona, F. M. 2017b. «Aporte a la Historia de la Provincia dominicana de Andalucía de fray Salvador Núñez, confesor del convento Madre de Dios de Baena». Archivo Dominicano 38: 171224.

Carmona Carmona, F. M. 2017c. «Obra y proyectos del gran cantero Luis González Bailén». Anales de Historia del Arte 27: 83-112. https://doi.org/10.5209/ANHA.57483

Concilio de Trento, 1798 (1564). El Sacrosanto y Ecuménico Concilio de Trento, traducido al idioma castellano por don Ignacio López de Ayala, 4ạ edición, Madrid: imprenta de Ramón Ruiz.

Domínguez Ortiz, A. 2012 (1973). Las clases privilegiadas en el Antiguo Régimen. Madrid: Ed. Akal.

Fernández de Béthencourt, F. 2003. Historia genealógica y heráldica de la monarquía española, Casa Real y grandes de España, 9 vols. Sevilla: Fabiola. 
Ferrer Valls, T. 2008. «Teatro y Mecenazgo en el Siglo de Oro: Lope de Vega y el Duque de Sessa», en A. Egido Martínez y J. E. Laplana Gil (coords.), Mecenazgo y Humanidades en tiempos de Lastanosa: 113-134. Huesca: Instituto Estudios Altoaragoneses-Institución Fernando El Católico.

Graña Cid, M. M. 2012. "Poder nobiliario y monacato femenino en e tránsito a la Edad Moderna (Córdoba, 1495-1550)». Cuadernos de Historia Moderna 37: 43-72. https://doi.org/10.5209/rev_chmo.2012.v37.39227

Huerga Teruelo, Á. 1992. Los dominicos en Andalucía. Sevilla: Taravilla. Jordano Barbudo, M. Á. 2002. El mudéjar en Córdoba. Córdoba: Diputación. Jordano Barbudo, M. Á. 2012. Escudos de Córdoba y provincia en fachadas y portadas. Córdoba: Universidad.

Kusche Zettelmeyer, M. 1991. «La antigua galería de retratos del Pardo: su reconstrucción arquitectónica y el orden de colocación de los cuadros». Archivo Español de Arte 64 (253): 1-28.

López Caparroso, J. (fray), obispo de Monopoli, 1622. Quinta parte de la Historia de Santo Domingo y de su Orden de Predicadores. Valladolid: Juan de Rueda editor.

Lorea Amescua, A. (fray) 1681-1683. Historia de la Provincia de Andalucía de la Orden de Predicadores, 2 tomos. Manuscrito del Archivo Histórico de la Provincia Dominicana de Andalucía (Dominicos): AHPDA, $10 / 1$ y 10/2. Versión digital accesible desde el Archivo General de la Región de Murcia: http://archivoweb.carm.es/archivoGeneral/
Martínez Caviró, B. 1991. Cerámica hispanomusulmana. Andalusí y mudéjar. Madrid: El Viso.

Miura Andrades, J. M. 1988a. «Las fundaciones dominicas en Andalucía 1236-1591», en Actas del I Congreso Internacional sobre los Dominicos y el Nuevo Mundo: 73-100. Sevilla: Fundación 'Instituto Bartolomé de las Casas'.

Miura Andrades, J. M. 1988b. "Las fundaciones de la Orden de Predicadores en el reino de Córdoba (I)». Archivo Dominicano 9: 267-372.

Morant Deusa, I. y Bolufer Peruga, M. 1998. Amor, matrimonio y familia. La construcción histórica de la familia moderna. Madrid: Síntesis.

Reder Gadow, M. 2000. "Las voces silenciosas de los claustros de clausura». Cuadernos de Historia Moderna 25: 279-335.

Ruiz Arjona, R. 1986. Baena, Testimonio de su historia. Baena: Ayuntamiento.

Soria Mesa, E. 2007. La nobleza en la España moderna. Cambio y continuidad. Madrid: Marcial Pons.

Soria Mesa, E. 2011. «La imagen del poder. Un acercamiento a las prácticas de visualización del poder en la España moderna». Historia y Genealogía 1: 5-10. https://doi.org/10.21071/hyg.v0i1.313

Valverde y Perales, F. 1903. Historia de la villa de Baena. Toledo: Viuda e hijos de J. Peláez. 